\title{
PRETORIA RADIOCARBON DATES III
}

\author{
J C VOGEL, ANNEMARIE FULS, and EBBIE VISSER \\ National Physical Research Laboratory, CSIR, Pretoria, South Africa
}

This list contains ${ }^{14} \mathrm{C}$ dates pertaining to the Stone Age in southern Africa and covers the region from Zambia in the north to Natal and the northern Cape Province in South Africa. The southern and southwestern Cape Province are not included. Descriptions are based on information supplied by the submitters.

Unless otherwise stated, all charcoal and wood samples are pretreated with hot dilute hydrochloric acid. The bone samples are gradually demineralized with a $1 \%$ hydrochloric acid solution which is renewed daily until the solution remains colorless after $24 \mathrm{hr}$. The collagen is then washed with distilled water in the same way until all acidity is removed. Experience has shown that when the acid remains colorless the contaminating organic material has been removed effectively and that a reliable date for the collagen can be obtained. In some instances, when environmental conditions under which the bones had been preserved were unfavorable and the collagen had been degraded, it is impossible to remove all the contaminating organic substances without dissolving all the collagen, and the acid solution remains yellow. Dates for such samples tend to be less reliable.

The pretreated samples are combusted, and after purification of the resulting carbon dioxide (Vogel \& Waterbolk, 1967) assayed for ${ }^{14} \mathrm{C}$ in two similar gas proportional counters described previously (Vogel \& Marais, 1971). Ostrich eggshell samples are treated directly with hydrochloric acid and the evolved $\mathrm{CO} \mathrm{O}_{2}$ collected for analysis. Where enough material is available the first fraction is discarded to minimize secondary contamination.

Ages are calculated using the conventional half-life of $5568 \mathrm{yr}$ for ${ }^{14} \mathrm{C}$. Corrections for variations in isotope fractionation, based on ${ }^{13} \mathrm{C}$ analysis of the $\mathrm{CO}_{2}$ gas, are applied to all dates. The most probable historic date for samples with ages of $<400 \mathrm{yr}$ is deduced from the calibration curve for the Southern Hemisphere and given in the comments where appropriate.

The general shape of the calibration curve has not changed since earlier measurement ( $c f$ Vogel, 1970, p 466), but the actual position on the graph, which depends on the absolute calibration of counters in different laboratories, has been improved. This intercalibration is at present probably not better that $\pm 20 \mathrm{yr}$ for most laboratories. In addition, the previously reported difference between ${ }^{14} \mathrm{C}$ dates for the Northern and Southern Hemispheres (Lerman, Mook \& Vogel, 1970) has recently been confirmed (Vogel et al, 1986) and our best estimate at present is that samples from mid-latitudes in the Southern Hemisphere are ca $30 \mathrm{yr}$ older than those from Europe. Taking both the current values for laboratory calibration and this effect into account, the calibration curve given in Figure 1 has been constructed, and this curve has been used for interpreting the Iron Age dates in this list. 


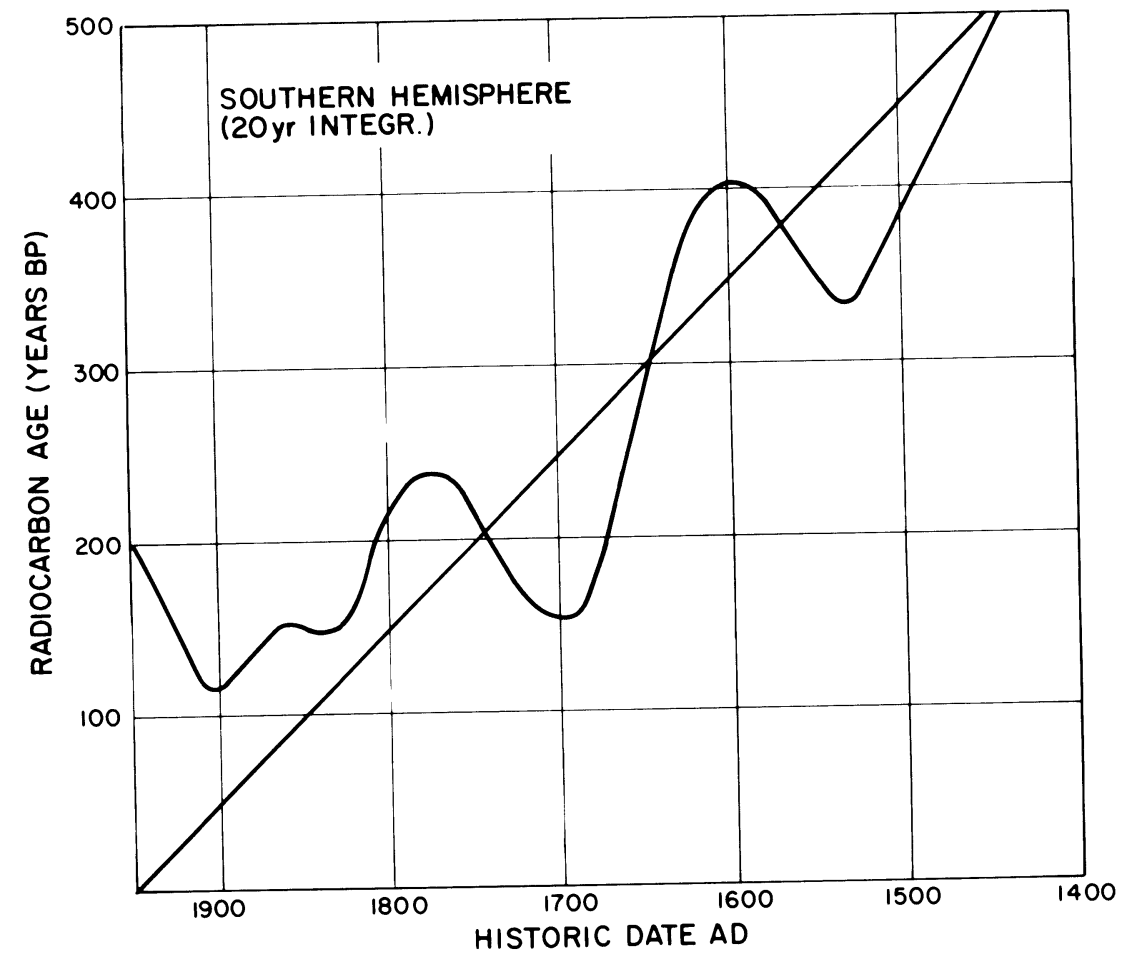

Fig 1. Calibration curve for samples from mid-latitudes in the Southern Hemisphere

\section{ACKNOWLEDGMENTS}

Thanks are due all those who, over the years, have helped with the processing of the samples, and especially to Siep Talma for supervising the ${ }^{13} \mathrm{C}$ analyses and ensuring that these remain highly reliable.

\section{Zambia}

\section{Mwambacimo Shelter series}

Mwambacimo rock shelter $\left(13^{\circ} 24^{\prime} \mathrm{S}, 28^{\circ} 45^{\prime} \mathrm{E}\right)$ near Ndola, Copperbelt Prov, $220 \mathrm{~cm}$ deposit containing Later Stone Age (LSA) assemblages. Coll and subm 1978 by F B Musonda, Livingstone Mus, Livingstone, Zambia.

\section{Pta-2409. Mwambacimo 1}

$$
\delta^{13} \mathrm{C}=-25.5 \%
$$

Charcoal from hearth in Layer I in SE corner of Pit A at $30 \mathrm{~cm}$ depth assoc with LSA assemblage and pottery. Comment: cal AD 1490-1640 (Fig $1)$. 
Pta-2410. Mwambacimo 2 with ISA.

Pta-2454. Mwambacimo 3A

$$
\begin{array}{r}
\mathbf{9 8 3 0} \pm \mathbf{9 0} \\
\delta^{13} C=-24.8 \% 0
\end{array}
$$
artifacts

Charcoal from Layer IIIA, Pit C at $130 \mathrm{~cm}$ depth assoc with LSA quartz

Pta-2453. Mwambacimo 3B

Charcoal from Layer IIIB, Pit C at $200 \mathrm{~cm}$ depth $20 \mathrm{~cm}$ above bedrock assoc with ISSA quartz artifacts.

General Comment: $c f$ dates from Chilimulilo and Mufulwe, below.

\section{Chilimulilo Shelter series}

Chilimulilo rock shelter $\left(13^{\circ} 24^{\prime} \mathrm{S}, 28^{\circ} 53^{\prime} \mathrm{E}\right)$ near Ndola, Copperbelt Prov. Deposit contains LSA assemblage. Samples coll and subm 1977 by F B Musonda.

\section{Pta-2176. Chilimulilo I}

$$
130 \pm 30
$$

Charcoal from Layer I, Pit Ia at $20 \mathrm{~cm}$ depth assoc with potsherds and I.SA artifacts. Comment: younger than cal AD 1810 but cal AD 1700 also possible.

\section{Pta-2178. Chilimulilo II}

Charcoal from Layer II, Pit I at $45 \mathrm{~cm}$ depth assoc wi LSA artifacts.

\section{Pta-2180. Chilimulilo III}

$$
\delta^{13} C=-25.4 \% 0
$$

Charcoal from Layer III, Pit I at 45 to $60 \mathrm{~cm}$ depth assoc with LSA artifacts. Comment: pretreated with acid and alkali.

\section{Pta-2181. Chilimulilo IV}

$$
\delta^{13} C=\begin{aligned}
& \mathbf{2 2 0} \pm \mathbf{3 5} \\
& -25.4 \% 0
\end{aligned}
$$

Charcoal from concentration near dripline in Layer IV, Pit Ia at $120 \mathrm{~cm}$ depth assoc with LSA assemblage. Comment: pretreated with acid and alkali. Cal AD 1660 or cal AD 1770.

General Comment: $c f$ dates from Mwambacimo, above and Mufulwe, below.

\section{Mufulwe Shelter series}

Mufulwe rock shelter ( $\left.13^{\circ} 58^{\prime} \mathrm{S}, 2^{\circ} 35^{\prime} \mathrm{E}\right) \mathrm{S}$ of Hwila, Central Prov. Shallow deposit with LSA assemblage (Musonda, 1984; Gutin \& Musonda, 1985). Samples coll and subm 1981 by F B Musonda. 
Pta-3255. Mufulwe 1

Charcoal from Layer 1 at 10 to $20 \mathrm{~cm}$ depth.

\section{Pta-3256. Mufulwe 2}

Charcoal from Layer 2 at 20 to $30 \mathrm{~cm}$ depth assoc with beginning of pottery manufacture in area.

\section{Pta-3257. Mufulwe 3}

$$
600 \pm 40
$$

Charcoal from Layer 2 at 30 to $40 \mathrm{~cm}$ depth assoc with pottery.

Pta-3258. Mufulwe 4

$$
\begin{array}{r}
\mathbf{1 4 6 0} \pm \mathbf{4 0} \\
\delta^{13} C=-24.8 \% 0
\end{array}
$$

Charcoal from Layer 2 at 40 to $50 \mathrm{~cm}$ depth underlying first occurrence of pottery and iron. Comment: pretreated with acid and alkali.

Pta-3259. Mufulwe 5

$$
\begin{array}{r}
\mathbf{1 6 9 0} \pm \mathbf{4 0} \\
\delta^{13} C=-25.5 \% 0
\end{array}
$$

Charcoal from Layer 3 at 70 to $100 \mathrm{~cm}$ depth assoc with microlithic assemblage and antedating pottery. Comment: pretreated with acid and alkali.

General Comment: contrary to opinion of excavators, Pta-3258 and -3259 for pre-pottery levels show Pta-3256: $2170 \pm 50 \mathrm{BP}$ unreliable as date for introduction of pottery. Microlithic assemblage in Layers 2 and 3 considered by excavators equivalent to Layer 3 in Mwambacimo, see above.

\section{Zimbabwe}

\section{Diana's Vow series}

Rock shelter on Diana's Vow farm $\left(18^{\circ} 21^{\prime} \mathrm{S}, 32^{\circ} 18^{\prime} \mathrm{E}\right) 33 \mathrm{~km} \mathrm{NE}$ of Rusape, Makoni dist, with unusual paintings. Deposit contains Early (EIA) and Later Iron Age (LIA) ceramics and four phases of Wilton industrial complex (Cooke, 1979). Samples coll 1976 by C K Cooke; subm 1976 by T M Huffman, Univ Witwatersrand, Johannesburg.

Pta-2001. Diana's Vow 1

Charcoal from Sq CDl $/ 2$ at 20 to $30 \mathrm{~cm}$ depth.

Pta-1858. Diana's Vow 3 
Pta-1857. Diana's Vow 5

Charcoal from Sq CD1/2 at 150 to $160 \mathrm{~cm}$ depth. Comment: pretreated with acid and alkali.

\section{Pta-2788. Craiglee Shelter}

$$
\begin{array}{r}
4260 \pm 60 \\
\delta^{13} C=-6.6 \% 0
\end{array}
$$

Ostrich eggshell from ca $4 \mathrm{~cm}$ depth in small granite overhang on Craiglee farm, Bulawayo dist $\left(20^{\circ} 08^{\prime} \mathrm{S}, 28^{\circ} 39^{\prime} \mathrm{E}\right)$ assoc with Wilton assemblage. Coll 1947; subm 1980 by C K Cooke, Natl Mus and Monuments, Bulawayo, Zimbabwe. Comment: first 5\% carbonate discarded, rest analyzed.

\section{Bambata Cave series}

Large Bambata cave $\left(20^{\circ} 30^{\prime} 10^{\prime \prime} \mathrm{S}, 28^{\circ} 24^{\prime} 25^{\prime \prime} \mathrm{E}\right)$ near summit of large bare granite hill in Matopos hills, ca $40 \mathrm{~km} \mathrm{~S}$ of Bulawayo. Deposit contains Bambata pottery (Jones, 1940; Walker, 1983) and LSA industry. Samples coll 1980; subm 1980 and 1982 by N J Walker, Queen Victoria Mus, Harare, Zimbabwe.

Pta-3477. Bambata BN 25

$$
\begin{array}{r}
\mathbf{2 8 5 0} \pm \mathbf{6 0} \\
\delta^{13} C=-25.3 \% 0
\end{array}
$$

Charcoal from Sq N, Layer IIIa at $28 \mathrm{~cm}$ depth assoc with final occupation of LSA (Late Matopan), pottery and sheep.

\section{Pta-3072. Bambata BN 32}

$$
\begin{array}{r}
\mathbf{2 1 4 0} \pm \mathbf{6 0} \\
\delta^{13} \mathrm{C}=-25.3 \% \text { o }
\end{array}
$$

Charcoal from hearth Unit PGA at $36 \mathrm{~cm}$ depth assoc with Bambata pottery, final LSA/early Iron Age transition. Comment: from same layer at Pta-3477, above.

\section{Pta-3111. Bambata N60}

$$
\begin{array}{r}
\mathbf{3 9 6 0} \pm \mathbf{6 0} \\
\delta^{13} C=-24.3 \% \text { o }
\end{array}
$$

Charcoal from Sq N, Unit GA, at $60 \mathrm{~cm}$ depth assoc with Bambata pottery, sheep/goat and possible cattle remains, and late LSA assemblage.

\section{Pta-3472. Bambata BN 108/111}

$5120 \pm 70$ and alkali.

General Comment: vertical mixing has obviously taken place in pottery levels and Pta-3477, -3072, and -3111 do not provide date for earliest ceramics in region.

\section{Cave of Bees series}

Cave of Bees $\left(20^{\circ} 30^{\prime} 15^{\prime \prime} \mathrm{S}, 28^{\circ} 30^{\prime} 35^{\prime \prime} \mathrm{E}\right), 5 \mathrm{~km} \mathrm{~N}$ of Pomongwe cave 
in Matopos hills, $\mathrm{S}$ of Bulawayo, containing $>1 \mathrm{~m}$ LSA deposit. Samples coll 1978; subm 1979 and 1982 by $\mathrm{N} \mathrm{J}$ Walker.

\section{Pta-2577. Cave of Bees IIIa}

Charcoal from Sq B, Layer IIIa at ca $34 \mathrm{~cm}$ depth.

\section{Pta-3459. Cave of Bees IIIb}

Ostrich eggshell from Sq B, Layer IIIa at $30 \mathrm{~cm}$ depth assoc with Matopan assemblage. Comment: first $16 \%$ carbonate removed with acid, remaining carbonate analyzed. This sample was analyzed as check on Pta-2577, above, which appeared to be too young for assoc artifacts.

\section{Pta-2578. Cave of Bees IV}

$\mathbf{1 0 , 5 0 0} \pm 100$

Charcoal from Sq B, Layer IV at ca $66 \mathrm{~cm}$ depth assoc with Pomongwe industry, small backed piece with traces of painting on spall of granite. Comment: pretreated with acid and alkali.

\section{Pta-2586. Cave of Bees V}

$$
\begin{array}{r}
11,000 \pm 100 \\
\delta^{13} C=-25.0 \%
\end{array}
$$

Charcoal from Sq B, Layer V at ca $90 \mathrm{~cm}$ depth assoc with LSA assemblage, slightly different from Layer IV, above. Comment: pretreated with acid and alkali.

\section{Pta-2585. Cave of Bees VI}

$12,800 \pm 120$

Charcoal from Sq B, Layer VI, overlying bedrock at ca $110 \mathrm{~cm}$ depth assoc with LSA assemblage. Comment: pretreated with acid and alkali.

General Comment: cf dates from Nswatugi, Pomongwe and Tshangula, below.

\section{Nswatugi Cave series}

Nswatugi cave $\left(20^{\circ} 32^{\prime} 10^{\prime \prime} \mathrm{S}, 28^{\circ} 28^{\prime} 30^{\prime \prime} \mathrm{E}\right)$, ca $5 \mathrm{~km} \mathrm{NW}$ of Pomongwe cave in Matopos hills, $S$ of Bulawayo. Top ca $1 \mathrm{~m}$ ash layer contains Matopan industry with scrapers predominating and backed tools increasing upwards. Underlying layer contains Pomongwe industry, thin relatively sterile orange-brown level, and $4 \mathrm{~m}$ of probable Middle Stone Age (MSA) deposit (Walker, 1980). Samples coll 1975; subm 1976 and 1980 by N J Walker.

\section{Pta-1768. Nswatugi E4c 12}

$6490 \pm 70$

Charcoal from Sq E4 at $10 \mathrm{~cm}$ depth assoc with LSA Matopan industry. 
Pta-3113. Nswatugi E4d.24/28

$7610 \pm 80$

$\delta^{13} \mathrm{C}=-23.5 \%$

Charcoal from Sq E4, Layer IIIb at $25 \mathrm{~cm}$ depth assoc with Matopan industry. Comment: pretreated with acid and alkali.

Pta-2046. Nswatugi F4ac 28

$7880 \pm 70$

Charcoal from Sq F4, Layer IV, at $26 \mathrm{~cm}$ depth assoc with Matopan industry and burned limb-bone fragments of teenager.

Pta-3116. Nswatugi D4b 88

$9220 \pm 90$

$\delta^{13} \mathrm{C}=-25.0 \%$

Charcoal from Sq D4, Layer V, at $88 \mathrm{~cm}$ depth assoc with Early Matopan assemblage. Comment: pretreated with acid and alkali.

Pta-1771. Nswatugi E4d 96

$9790 \pm 90$
$\delta^{13} C=-25.8 \%$

Charcoal from Sq E4 at 91 to $95 \mathrm{~cm}$ depth assoc with Pomongwe assemblage, base of LSA. Comment: pretreated with acid and alkali.

\section{Pta-2218. Nswatugi D4 124/128}

$$
\begin{array}{r}
10,270 \pm 90 \\
\delta^{13} C=-24.7 \% 0
\end{array}
$$

Charcoal from Sq D4, orange-brown soil level at ca 120 to $128 \mathrm{~cm}$ depth assoc with human burial. Comment: pretreated with acid and alkali.

\section{Pta-1772. Nswatugi E4b 124/128}

$$
\delta^{I 3} C=-25.5 \%
$$

Charcoal from Sq E4 at 120 to $128 \mathrm{~cm}$ depth assoc with end of MSA Tshangula industry. Comment: pretreated with acid and alkali.

General Comment: $c f$ dates from Pomongwe, below.

\section{Pta-2570. Kalanyoni Shelter}

$$
\begin{array}{r}
\mathbf{5 7 6 0} \pm \mathbf{7 0} \\
\delta^{13} C=-7.5 \% 0
\end{array}
$$

Ostrich eggshell from Unit IV-VII in Kalanyoni rock shelter $\left(20^{\circ} 32^{\prime} 20^{\prime \prime} \mathrm{S}, 28^{\circ} 29^{\prime} 5^{\prime \prime} \mathrm{E}\right)$ ca $3 \mathrm{~km}$ NW of Pomongwe shelter in Matopos hills, S of Bulawayo, assoc with LSA Matopan industry. Sample coll 1978; subm 1979 by N J Walker. Comment: first $13.1 \%$ carbonate discarded, rest analyzed.

\section{Pta-2648. Maleme Shelter}

$$
\begin{array}{r}
\mathbf{4 7 4 0} \pm \mathbf{7 0} \\
\delta^{13} C=-7.1 \% 0
\end{array}
$$

Ostrich eggshell from Units III-VIII at 8 to $60 \mathrm{~cm} \mathrm{depth,} \mathrm{in} \mathrm{Maleme}$ Dam shelter $\left(20^{\circ} 32^{\prime} 25^{\prime \prime} \mathrm{S}, 28^{\circ} 30^{\prime} 5^{\prime \prime} \mathrm{E}\right) \mathrm{ca} 1 \mathrm{~km} \mathrm{NW}$ of Pomongwe shelter, in Matopos hills, S of Bulawayo, assoc with LSA Matopan industry with many backed tools. Sample coll 1978; subm 1979 by N J Walker. Comment: first $11.8 \%$ carbonate discarded, rest analyzed. 


\section{Pomongwe Cave series}

Very large Pomongwe cave with paintings, almost on ground level, in Matopos hills $\left(20^{\circ} 32^{\prime} 50^{\prime \prime} \mathrm{S}, 28^{\circ} 30^{\prime} 45^{\prime \prime} \mathrm{E}\right)$, Matopo Natl Park. Ca $4 \mathrm{~m}$ deposit contains long sequence of Stone Age assemblages (Cooke, 1963; Walker, 1980). Coll 1960 by C K Cooke and 1979 by N J Walker; subm 1980 by $\mathrm{N} J$ Walker.

\section{Pta-3085. Pomongwe PZ 4/5}

$$
\begin{array}{r}
\mathbf{4 0 9 0} \pm \mathbf{7 0} \\
\delta^{13} C=-25.2 \% 0
\end{array}
$$

Charcoal from Tr 5 , Unit UWA at 5 to $8 \mathrm{~cm}$ depth assoc with Matopan assemblage, final occupation by LSA people.

Pta-3083. Pomongwe PM30

$4810 \pm 80$

$\delta^{13} C=-22.8 \%$ o

Charcoal from $\operatorname{Tr} 5$, Unit PBA at $32 \mathrm{~cm}$ depth assoc with Matopan assemblage.

\section{Pta-3470. Pomongwe M55}

$8420 \pm 80$

$\delta^{13} C=-21.8 \%$

Charcoal from hearth in Sq M, Unit VII at $68 \mathrm{~cm}$ depth assoc with Early Matopan assemblage. Comment: date for granite spalls with paint.

\section{Pta-3117. Pomongwe M90}

$9500 \pm 120$

Charcoal from Sq M, Unit BA at ca $87 \mathrm{~cm}$ depth assoc with Early Pomongwe.

$$
\delta^{13} C=-24.3 \%
$$

Pta-3118. Pomongwe Y78

$12,300 \pm 100$

Charcoal from Sq Y, Unit BA at ca $110 \mathrm{~cm}$ depth level appears to correlate with Cooke's (1963) Tshangula level Pta-2300, -2299, below.

\section{Pta-3119. Pomongwe Y87}

$13,000 \pm 120$

Charcoal from Sq Y, Unit GB at ca $140 \mathrm{~cm}$ depth.

Samples from Cooke's excavation

\section{Pta-2306. Pomongwe 1C}

$$
\mathbf{8 5 4 0} \pm \mathbf{9 0}
$$

Charcoal from Sq E-G/3-5, Cook's Layer 3, Unit GA at ca $30 \mathrm{~cm}$ depth assoc with Matopan assemblage. Comment: $c f$ other dates from Pomongwe, SR-14: $7610 \pm 110$ (Layer 2); SR-93: 9410 \pm 120 BP (Cooke, 1963, p 149). 
Pta-2300. Pomongwe 4A

$11,020 \pm 60$ with Tshangula assemblage.

\section{Pta-2299. Pomongwe 4E}

$14,900 \pm 120$

Charcoal from Sq E-G/8-10, Layer 4, Unit BA at ca $1 \mathrm{~m}$ depth assoc with beginning of Tshangula assemblage. Comment: of date from Pomongwe, Layer 4b, SR-1 1: 15,800 \pm 200 BP (Cooke, 1963, p 149).

General Comment: all samples pretreated with acid and alkali.

\section{Shashabugwa Shelter series}

Shashabugwa shelter $\left(20^{\circ} 33^{\prime} 55^{\prime \prime} \mathrm{S}, 28^{\circ} 33^{\prime} 30^{\prime \prime} \mathrm{E}\right)$ ca $5 \mathrm{~km}$ SE of Pomongwe cave in Matopos hills, $\mathrm{S}$ of Bulawayo; $2.8 \mathrm{~m}$ deposit with Iron Age, LSA, and MSA layers (Walker, 1980). Samples coll and subm between 1971 and 1979 by $\mathrm{N} \mathrm{J}$ Walker.

\section{Pta-2217. Shashabugwa TII}

$\mathbf{1 1 1 0} \pm \mathbf{5 0}$

Charcoal from Tr II, gray ash layer at 70 to $85 \mathrm{~cm}$ depth, just below lower level of pottery, assoc with Matopan assemblage. Comment: pretreated with acid and alkali.

\section{Pta-2647. Shashabugwa 3}

$$
\begin{array}{r}
\mathbf{7 9 3 0} \pm \mathbf{8 0} \\
\delta^{13} C=-6.5 \% \text { o }
\end{array}
$$

Ostrich eggshell from $\operatorname{Tr} 1$, Layer 1 at 85 to $90 \mathrm{~cm}$ depth assoc with Matopan assemblage. Comment: first $12.5 \%$ carbonate discarded, rest analyzed.

\section{Pta-2569. Shashabugwa 2}

$$
\begin{array}{r}
\mathbf{8 9 2 0} \pm \mathbf{8 0} \\
\delta^{13} C=-5.9 \%
\end{array}
$$

Ostrich eggshell from $\operatorname{Tr} 1$, base of Layer 1 at 145 to $163 \mathrm{~cm}$ depth assoc with Matopan industry. Comment: outer carbonate removed with acid, rest analyzed.

General Comment: $c f$ dates from Pomongwe and Nswatugi, above.

\section{Tshangula Cave series}

Tshangula cave $\left(20^{\circ} 38^{\prime} \mathrm{S}, 28^{\circ} 32^{\prime} \mathrm{E}\right)$ with rock paintings in Matopos hills, ca $10 \mathrm{~km}$ S of Pomongwe cave (Cooke, 1963). Samples coll 1963; subm 1979 by C K Cooke.

\section{Pta-2472. Tshangula Level 1}

$$
\begin{array}{r}
\mathbf{8 5 6 0} \pm \mathbf{8 0} \\
\delta^{13} C=-6.4 \% 0
\end{array}
$$

Ostrich eggshell beads from Sq BC 3 to 4 at $7.5 \mathrm{~cm}$ depth, Level 1, assoc with Matopan assemblage and single human metatarsal with notch at 
one end (Walker, 1980). Comment: first $9.5 \%$ carbonate discarded, rest analyzed.

\section{Pta-2473. Tshangula Level 3}

$$
\begin{array}{r}
9760 \pm 90 \\
\delta^{13} C=-6.5 \%
\end{array}
$$

Ostrich eggshell beads from Sq DC 2 to 5 at 45 to $63 \mathrm{~cm}$ depth assoc with Pomongwe phase of LSA. Comment: first $10 \%$ sample discarded, rest analyzed.

General Comment: dates from Zimbabwe collectively suggest Wilton-type Matopan (or Khami) industries already present in region before $9000 \mathrm{BP}$ (Pta-3459, -3116, -3470, -2306, -2569, -2472), thus antedating earliest Wilton in S Cape Prov. Albany-type Pomongwe industry gives dates between $10,500 \mathrm{BP}$ (Pta-2578) and 9500 BP (Pta-3117), and Tshangula industry at Pomongwe dates between 15,000 and 11,000 BP.

\section{Mtanye Stream series}

Rock shelter with paintings near Mtanye stream $\left(21^{\circ} 22^{\prime} 55^{\prime \prime} \mathrm{S}\right.$, $29^{\circ} 15^{\prime} 15^{\prime \prime} \mathrm{E}$ ) on Doddieburn Ranch, ca $50 \mathrm{~km} \mathrm{~S}$ of West Nicholson, SW Zimbabwe; $84 \mathrm{~cm}$ deposit with LSA assemblage. Samples coll 1972; subm 1973 by $\mathrm{N} J$ Walker.

\section{Pta-967. Mtanye Stream 1}

$410 \pm \mathbf{4 5}$

$\delta^{13} C=-24.4 \%$ o

Charcoal from Level B at 15 to $20 \mathrm{~cm}$ depth assoc with Iron Age and I.SA artifacts.

\section{Pta-969. Mtanye Stream 2}

$$
\delta^{13} C=\begin{array}{r}
\mathbf{4 8 0} \pm \mathbf{4 0} \\
-24.6 \%
\end{array}
$$

Charcoal from top of I evel C at 25 to $30 \mathrm{~cm}$ depth assoc with Matopan assemblage and Bambata pottery.

\section{Pta-968. Mtanye Stream 3}

$$
\delta^{13} C=-24.5 \%
$$

Charcoal from bottom of Level $C$ at 30 to $40 \mathrm{~cm}$ depth assoc with Matopan assemblage and potsherds.

General Comment: much younger than expected. Cf dates from Dombazonga shelter SR-15: 2700 $\pm 100 \mathrm{BP}$ (unpub).

\section{Swaziland}

\section{Langubhela Shelter series}

Langubhela rock shelter $\left(26^{\circ} 17^{\prime} \mathrm{S}, 31^{\circ} 10^{\prime} \mathrm{E}\right)$ near Mbabane, with MSA, ISA, and Iron Age horizons, was excavated in 1980. Samples subm 1982 by David Price-Williams, Swaziland Natl Trust Comm Lobamba, Swaziland.

\section{Pta-3346. Langubhela 1}

Charcoal from Sq J10 at 54 to $65 \mathrm{~cm}$ depth assoc with Iron Age. 
Pta-3347. Langubhela 2

Charcoal from Sq J10 at 70 to $75 \mathrm{~cm}$ depth assoc with LSA. Comment: pretreated with acid and alkali.

Pta-3349. Langubhela 4

$\mathbf{3 1 , 4 0 0 \pm 7 8 0}$

$\delta^{13} \mathrm{C}=-25.0 \%$

Charcoal from Sq O9 at 186 to $192 \mathrm{~cm}$ depth assoc with MSA unifacial and bifacial points. Comment: pretreated with acid and alkali.

Pta-3348. Langubhela 3

$42,700+2600$

$\delta^{13} \mathrm{C}=-25.2 \%$

Charcoal from Sq L10 at 159 to $164 \mathrm{~cm}$ depth assoc with convergent points and side scrapers of MSA, lowest stratum at site.

\section{Siphiso Shelter series}

Siphiso rock shelter $\left(26^{\circ} 18^{\prime} \mathrm{S}, 31^{\circ} 58^{\prime} \mathrm{E}\right)$ on scarp face of Lebombo Mts, NE Swaziland, has $4.6 \mathrm{~m}$ LSA deposits. Samples subm 1982 by David Price-Williams.

Pta-3533. Siphiso H8.1.8

$$
\begin{array}{r}
\mathbf{7 6 0 0} \pm \mathbf{8 0} \\
\delta^{13} C=-19.8 \% \text { o }
\end{array}
$$

Charred bone from Sq $\mathrm{H} 8$, at 42 to $44 \mathrm{~cm}$ depth, underlying Classic Wilton assemblage.

\section{Pta-3540. Siphiso H8.3.9}

$8700 \pm 120$

Charred bone from Sq $\mathrm{H} 8$, Loc 3 at 75 to $77 \mathrm{~cm}$ depth assoc with PreWilton Lebombo industry.

General Comment: pretreated as for charred bone (Vogel \& Waterbolk, 1963) and alkali soluble fraction measured. $C f$ Belleview Shelter, below.

\section{Pta-371. Cauldwell Shelter}

$6750 \pm 70$

$\delta^{13} \mathrm{C}=-26.1 \%$

Charcoal from Sqs N0, N1, and N2 at 53 to $70 \mathrm{~cm}$ depth, basal level of deposit in Cauldwell rock shelter, $6 \mathrm{~km} \mathrm{~N}$ of Mbabane $\left(26^{\circ} 20^{\prime} \mathrm{S}, 31^{\circ} 10^{\prime} \mathrm{E}\right)$, assoc with LSA assemblage. Coll 1969; subm 1970 by P B Beaumont, McGregor Mus, Kimberley. Comment: pretreated with acid and alkali.

\section{Lesotho}

\section{Melikane Shelter series}

Large Melikane shelter $\left(29^{\circ} 57^{\prime} \mathrm{S}, 28^{\circ} 45^{\prime} \mathrm{E}\right)$ above tributary of Orange $\mathrm{R}$ in Drakensberg, ca $18 \mathrm{~km}$ N of Qacha's Nek (Carter, 1976). Samples coll and subm 1974 by P L Carter. 


\section{Pta-1364. Melikane 1}

Organic material from Sq P9 in Layer 1 assoc with LSA assemblage.

\section{Pta-1367. Melikane 6}

$19,700 \pm 150$

$\delta^{13} C=-23.5 \%$

Organic material from Sq R9, Layers $2 / 3$ assoc with microlithic (?) early LSA assemblage. Comment: pretreated with acid and alkali.

\section{Pta-1407. Melikane 2}

$20,200 \pm 150$

Charcoal from Sq Q8 Layers 2/3. Comment: pretreated with acid and alkali.

$\delta^{13} C=-23.9 \%$

\section{Pta-1406. Melikane 3}

$$
20,000 \pm 170
$$

Charcoal from Sq Q9 Layers 2/3. Comment: pretreated with acid and alkali.

Pta-1408. Melikane 9

$33,100 \pm 600$

Charcoal from Sq R8, top of Layer 4 assoc with MSA assemblage. Comment: pretreated with acid and alkali.

Pta-1331. Melikane 19

$\mathbf{3 5 , 8 0 0} \pm \mathbf{9 2 0}$

$\delta^{13} C=-23.4 \%$

Charcoal from Sq Q7, top of Layer 4. Comment: pretreated with acid and alkali.

\section{Pta-1534. Melikane 24}

$42,000 \pm 1700$

Charcoal from Sq Q5, bottom of Layer 4 .

$$
\delta^{13} \mathrm{C}=-24.9 \%
$$

\section{Pta-1330. Melikane 25}

$42,300 \pm 2100$

$\delta^{13} C=-24.3 \%$ o

Charcoal from Sq Q6, top of Layer 5 assoc with MSA assemblage. Comment: pretreated with acid and alkali.

Pta-1369. Melikane 10

$33,800 \pm 960$

Charcoal from Sq R9, Layer 5. Comment: pretreated with acid and alkali.

Pta-1370. Melikane 29

$40,200 \pm 1650$

$\delta^{13} C=-23.6 \%$

Organic material from $\mathrm{Sq} Q 7$, top of Layer 6. Comment: pretreated with acid and alkali. 
Pta-1372. Melikane 33

Organic material from Sq P6, Layer 6.

\section{Pta-1371. Melikane 36}

Charcoal from Sq P5, Layer 6.

General Comment: dates for Layer 6 obviously too young. Cf related dates from Belleview, Moshebi's, Ha Soloja, and Sehonghong series, below.

\section{Moshebi's Shelter series}

Moshebi rock shelter $\left(29^{\circ} 56^{\prime} 15^{\prime \prime} \mathrm{S}, 29^{\circ} 01^{\prime} 50^{\prime \prime} \mathrm{E}\right)$ in Drakensberg, $7 \mathrm{~km} \mathrm{SW}$ of Sehlabathebe, E Lesotho. MSA and LSA deposits are present (Carter, 1969; Carter \& Vogel, 1974). Samples coll and subm 1970 by P L Carter.

\section{Pta-314. Moshebi 52}

$$
\delta^{13} C=\begin{aligned}
& \mathbf{2 6 0} \pm \mathbf{4 5} \\
& -24.7 \% 0
\end{aligned}
$$

Charcoal from Sq J10, Spit 2 with bone points, tanged or barbed points and pottery. Comment: pretreated with acid and alkali. Most probable cal date AD 1650.

\section{Pta-319. Moshebi 54}

$$
\begin{array}{r}
\mathbf{2 1 8 0} \pm \mathbf{4 5} \\
\delta^{13} C=-25.4 \%
\end{array}
$$

Charcoal from Sq J9, Spit 4 from back of shelter. Comment: artifacts in this spit belong to pre-pottery industry, but one barbed point was found. General Comment: see related dates for tanged/barbed points from Belleview and Sehonghong, below.

\section{Ha Soloja Shelter series}

Ha Soloja rock shelter $\left(29^{\circ} 51^{\prime} 05^{\prime \prime} \mathrm{S}, 29^{\circ} 03^{\prime} \mathrm{E}\right)$ in catchment area of Orange R 5km NW of Sehlabathebe, Qacha's Nek dist. Uppermost deposit was removed during occupation in late 19 th century; $3.25 \mathrm{~m}$ intact deposit contains only MSA artifacts (Carter \& Vogel, 1974). Samples coll and subm 1971 by P L Carter.

\section{Pta-741. Ha Soloja 7}

$\mathbf{3 8 , 8 0 0} \pm \mathbf{2 2 0 0}$

Charcoal from Sq C5, Spit 5A, Layer 2 at $30 \mathrm{~cm}$ depth, assoc with terminal MSA assemblage.

\section{Pta-771. Ha Soloja 8a}

$$
\begin{array}{r}
42,500+2500 \\
-1900 \\
\delta^{13} C=-24.6 \%
\end{array}
$$

Charcoal from Sq C7, Spit 5B, Layer 2 at 30 to $35 \mathrm{~cm}$ depth. 


\section{Pta-936. Ha Soloja 8b}

$$
\begin{array}{r}
45,000+\mathbf{2 6 0 0} \\
-\mathbf{3 9 0 0} \\
\delta^{13} C=-24.6 \% 0
\end{array}
$$

Charcoal from Sq C7, Spit 5B, Layer 2 at 30 to $40 \mathrm{~cm}$ depth. Comment: pretreated with acid and alkali, sample from same layer as Pta-771, above.

Pta-760. Ha Soloja 16

Charcoal from hearth in Sq C 5/6, Spit 9, Layer 2 at $80 \mathrm{~cm}$ depth, assoc with main MSA occupation.

General Comment: all results to be considered min ages.

\section{Sehonghong Shelter series}

Sehonghong rock shelter $\left(29^{\circ} 46^{\prime} 5^{\prime \prime} \mathrm{S}, 28^{\circ} 47^{\prime} 10^{\prime \prime} \mathrm{E}\right)$ ca $28 \mathrm{~km} \mathrm{NE}$ of Melikane shelter (see above), in Orange R catchment of Drakensberg. $3 \mathrm{~m}$ deposit contains LSA and MSA assemblages. Microblade assemblage with small lamellar blades and cone-shaped microcones clearly overlies MSA layers (Carter \& Vogel, 1974). Samples coll and subm 1971-1973 by P L. Carter.

\section{Pta-885. Sehonghong 2}

$$
\begin{array}{r}
\mathbf{1 4 0 0} \pm \mathbf{5 0} \\
\delta^{13} C=-24.2 \%
\end{array}
$$

Charcoal from hearth in Sq K8, Spit 2 at $15 \mathrm{~cm}$ depth assoc with pressure-flaked tanged point horizon of LSA. Comment: pretreatment with acid and alkali. Related dates, Belleview Pta-291: 1590 \pm 60 , below.

\section{Pta-884. Sehonghong 12}

$13,000 \pm 140$

Charcoal from Sq K8, Spit 5 at 45 to $50 \mathrm{~cm}$ depth in top of Layer 9. Comment: pretreated with acid and alkali.

\section{Pta-789. Sehonghong 13}

$20,900 \pm 270$

$$
\delta^{13} \mathrm{C}=-22.4 \%
$$

Charcoal from Sq K9, Spit 6, Layer 9 at $60 \mathrm{~cm}$ depth. Comment: pretreated with acid and alkali.

\section{Pta-918. Sehonghong 17}

$19,900 \pm 220$

Charcoal from Sq K8, Spit 7, Layer 9 at 60 to $70 \mathrm{~cm}$ depth. Comment: pretreated with acid and alkali.

\section{Pta-919. Sehonghong 18}

$20,200 \pm 230$

Charcoal from Sq K8, Spit 8, Layer 9 at 70 to $80 \mathrm{~cm}$ depth. Comment: pretreated with acid and alkali. Layer 9 contains micro-blade industry identical to Pre-Wilton at Rose Cottage, below, and Robberg industry at Nelson Bay cave (Deacon, 1982). 


\section{Pta-920. Sehonghong 19}

$\mathbf{2 8 , 9 0 0} \pm \mathbf{5 2 0}$
$\delta^{13} \mathrm{C}=-23.8 \% 0$

Charcoal from Sq I9, Spit 10 at 60 to $70 \mathrm{~cm}$ depth assoc with terminal MSA assemblage. Comment: pretreated with acid and alkali.

\section{Pta-787. Sehonghong 20}

$30,900 \pm 550$

Charcoal from hearth in $\mathrm{Sq} J 9$, Spit $10 / 11$ at $110 \mathrm{~cm}$ depth assoc with MSA assemblage and intense rock spalling. Comment: pretreated with acid and alkali.

\section{Pta-785. Sehonghong 37}

$32,200 \pm 770$

Charcoal from Sq I8/9, Spit 13 at $130 \mathrm{~cm}$ depth assoc with MSA assemblage, underlying roof spall layer. Comment: pretreated with acid and alkali.

\section{South Africa}

Transuaal

Pta-2854. Mwulu's Cave

$26,000 \pm 280$

$\delta^{13} \mathrm{C}=-24.8 \%$

Charcoal from Sq OP 45 at 40 to $45 \mathrm{~cm}$ below datum in red layer in Mwulu's cave $\left(24^{\circ} 10^{\prime} \mathrm{S}, 29^{\circ} 15^{\prime} \mathrm{E}\right)$, Strydpoort Mts, E of Potgietersrust, Potgietersrust dist, assoc with Pietersburg industry. Coll and subm 1979 by Eileen Aldworth, Univ Cambridge, UK. Comment: pretreated with acid and alkali. Probably too young; see Border Cave, below.

\section{Kruger Cave series}

Kruger cave, Magaliesberg at Olifantsnek, ca $17 \mathrm{~km} \mathrm{~S}$ of Rustenburg $\left(25^{\circ} 45^{\prime} \mathrm{S}, 27^{\circ} 14^{\prime} \mathrm{E}\right)$. Deposit contains well-preserved plant remains and I.SA asscmblage (Mason, 1974). Samples coll and subm 1974 by R J Mason, Univ Witwatersrand, Johannesburg.

\section{Pta-1273. Kruger Cave 1}

$9100 \pm 90$

Charcoul from back of cave at 10 to $20 \mathrm{~cm}$ depth, assoc with Sinihfict artifacts.

\section{Pta-1272. Kruger Cave 2}

$$
\begin{array}{r}
\mathbf{1 0 , 1 5 0} \pm \mathbf{9 0} \\
\delta^{13} C=-24.4 \% 0
\end{array}
$$

Charcoal from back of cave at 30 to $35 \mathrm{~cm}$ depth, assoc with Smithfield stone tools.

General Comment: samples pretreated with acid and alkali. 
Pta-3563. Jubilee Shelter

$$
\begin{array}{r}
\mathbf{3 7 3 0} \pm \mathbf{6 0} \\
\delta^{13} C=-26.3 \% 0
\end{array}
$$

Charcoal from Sq D1 at $72 \mathrm{~cm}$ depth from Jubilee shelter on Magalieskloof Pleasure Resort in Magaliesberg, $8 \mathrm{~km}$ E of Hartebeespoort Dam $\left(25^{\circ} 41^{\prime} \mathrm{S}, 27^{\circ} 54^{\prime} \mathrm{E}\right)$, Brits dist, assoc with LSA assemblage including stone segments. Coll 1982; subm 1983 by Lyn Wadley, Univ Witwatersrand.

\section{Bushman Rock Shelter series}

Bushman Rock shelter $\left(24^{\circ} 35^{\prime} \mathrm{S}, 30^{\circ} 38^{\prime} \mathrm{E}\right)$ on Klipfonteinhoek farm, near Echo cave, Ohrigstad dist, excavated in 1965 by A W Louw (1969; Vogel, 1970), and in 1970s by J F Eloff. Deposit contains MSA levels overlain by LSA horizons. Re-excavation provided material for artifactual and faunal analysis (Plug, 1981). Samples from new excavation subm 1972 by J F Eloff, Univ Pretoria.

\section{Pta-1175. Bushman Rock A}

$12,300 \pm 120$

$\delta^{13} C=-24.7 \%$

Charcoal from Sq C6, Layer 14a (Louw's Layer 24), at 132cm depth.

Pta-1176. Bushman Rock B

$12,500 \pm 120$

$\delta^{13} C=-24.5 \%$

Charcoal from Sq C6, Layer 16 (Louw's Layer 25), at $137 \mathrm{~cm}$ depth, base of LSA levels.

\section{Pta-1177. Bushman Rock C}

$12,800 \pm 80$

Charcoal from Sq C6, Layer 17 (Louw's Layer 28), at $150 \mathrm{~cm}$ depth, top of roof-spall level.

\section{Pta-1178. Bushman Rock D}

$12,950 \pm 70$

Charcoal from Sq C6, Layer 18 (Louw's Layer 29, 30), at $155 \mathrm{~cm}$ depth, main level of roof-spall.

\section{Pta-1179. Bushman Rock Ea}

$$
\begin{array}{r}
\mathbf{4 3 , 3 0 0} \begin{array}{r}
+\mathbf{3 1 0 0} \\
-\mathbf{2 3 0 0}
\end{array} \\
\delta^{13} \mathrm{C}=-24.1 \% 0
\end{array}
$$

Charcoal from Sq C6, Layer 19 (Louw's Layers 31-33), at $180 \mathrm{~cm}$ depth, underlying roof-spall, assoc with MSA assemblage. Comment: since practically whole sample was dissolved in sodium hydroxide, this soluble fraction was acidified and precipitate measured. Result is thus min date only. Cf GrN-51 16: >53,000 BP for Layer 38 (Vogel, 1970, p 459).

\section{Pta-1242. Bushman Rock Eb}

$$
23,900 \pm 320
$$

Charcoal from same Sq C6, Layer 19, at $180 \mathrm{~cm}$ depth. Comment: sample treated less vigorously with acid and alkali than Pta-1 179, and insoluble 
fraction measured. Age difference from Pta-1 179 suggests that this sample is mixed with younger material.

General Comment: all samples pretreated with acid and alkali. Results confirm previous dates (Vogel, 1970, p 458-460), specifically that charcoal in roof-spall level $(17,18)$ that contains MSA artifacts is derived from overlying LSA occupation. Weathering of roof-spall indicates long hiatus before re-occupation (Butzer, pers commun), strongly suggesting that MSA occupation ended before 53,000 BP. Derived MSA artifacts in LSA levels indicate considerable churning of deposit, and dates on bone from Layers 14, 15, 21 (Protsch \& de Villiers, 1974) are considered only min ages for MSA material.

Natal

\section{Border Cave series}

Border cave just below crest of steep $\mathrm{W}$ face of Lebombo range $\left(27^{\circ} 1^{\prime} 19^{\prime \prime} \mathrm{S}, 31^{\circ} 59^{\prime} 24^{\prime \prime} \mathrm{E}\right)>400 \mathrm{~m}$ above Swaziland Lowveld, $7 \mathrm{~km} \mathrm{~N}$ of Ingwavuma $\mathrm{R}$ gorge, KwaZulu. Excavation revealed upper Iron Age deposit with early LSA horizon and MSA levels, with anatomically modern Homo sapiens remains dated to $>49,000 \mathrm{BP}$ (Beaumont, 1973; Beaumont, de Villiers \& Vogel, 1978; Butzer, Beaumont \& Vogel, 1978). Coll and subm between 1970 and 1972 by B P Beaumont.

\section{Pta-870. Border Cave 1}

$170 \pm 45$

Plant remains from Sq T21 in brown sand upper layer, 1 BSU, at 8 to $15 \mathrm{~cm}$ depth assoc with Iron Age. Comment: cal date is post-AD 1660 .

Pta-715. Border Cave 2

$$
\begin{array}{r}
\mathbf{4 4 0} \pm \mathbf{6 0} \\
\delta^{13} C=-21.6 \% 0
\end{array}
$$

Twigs from Sq T19, Layer 1 BSU, Excavation 3A, at 30 to $38 \mathrm{~cm}$ depth assoc with base of Iron Age levels. Comment: pretreated with acid and alkali.

\section{Pta-703. Border Cave 3}

$500 \pm 45$

Plant remains from Sq T22, Layer $1 \mathrm{BSU}$, Excavation 3A, at 7.5 to $15 \mathrm{~cm}$ depth assoc with Iron Age. Comment: pretreated with acid and alkali.

\section{Pta-777. Border Cave Skeleton BC4}

$$
340 \pm 45
$$

Collagen from humerus of partly exposed Skeleton $\mathrm{BC} 4$, outside apparently buried from present surface of Layer $1 \mathrm{BSU}$, in $\mathrm{S}$ portion of cave. Comment: $4.0 \mathrm{~g}$ purified collagen extracted. Cal date is AD 14901640 . 


\section{Pta-1318. Border Cave Skeleton BC4}

Collagen from rib-bone of Skeleton BC4. Comment: $10 \mathrm{~g}$ collagen combusted yielded $1.4 \mathrm{~g}$ C. Skeleton was painted with glyptol which could explain two different dates. Average for two measurements: $410 \mathrm{BP}$.

\section{Pta-506. Border Cave 4}

$$
\mathbf{2 0 1 0} \pm \mathbf{5 0}
$$

Charcoal from Sq S19, Layer 1 BSU, Excavation 3A, at 38 to $46 \mathrm{~cm}$ depth assoc with a few undiagnostic stone artifacts and potsherds which are probably intrusive.

\section{Pta-721. Border Cave 5}

$$
13,300 \pm 150
$$

Charcoal from Sq S19, Laver 1 BSU, Excavation 3A at 46 to $53 \mathrm{~cm}$ depth assoc with a few undiagnostic stone artifacts. Comment: pretreated with acid and alkali.

\section{Pta-704. Border Cave 6}

$38,600 \pm 1500$

$$
\delta^{13} C=-24.3 \%
$$

Charcoal from Sq S21 in base of first brown sand lower layer, 1 BSL, Excavation $3 \mathrm{~A}$, at $69 \mathrm{~cm}$ depth assoc with early LSA. Comment: pretreated with acid and alkali.

\section{Pta-446. Border Cave 7, acid only}

\section{Pta-422. Border Cave 7, residue}

$\mathbf{3 7 , 5 0 0} \pm \mathbf{1 2 0 0}$
$\delta^{13} \mathrm{C}=-23.9^{\%} \% 0$

$$
36,800 \pm 1000
$$$$
\delta^{13} \mathrm{C}=-24.3 \%
$$
$3 \mathrm{~A}$ assoc with early LSA. Comment: Pta-446 pretreated with acid only, another portion of sample pretreated with acid and alkali and insoluble residue measured. Similarity of two dates suggests very little contamination.

\section{Pta-423. Border Cave 8}

$$
\begin{array}{r}
\mathbf{3 6 , 1 0 0} \pm \mathbf{9 0 0} \\
\delta^{13} \mathrm{C}=-24.2 \% 0
\end{array}
$$

Charcoal from middle of Layer 1 WA, Sq T21, Excavation 3A assoc with early LSA. Comment: pretreated with acid and alkali.

\section{Pta-424. Border Cave 9}

$$
\begin{array}{r}
\mathbf{3 5 , 7 0 0} \pm \mathbf{1 1 0 0} \\
\delta^{13} \mathrm{C}=-24.2 \% 0
\end{array}
$$

Charcoal from base of Layer $1 \mathrm{WA}$, Sq T21, Excavation 3A assoc with carly LSA. Comment: pretreated with acid and alkali. 
Pta-1190. Border Cave 10

$$
45,000+2800
$$

$\delta^{13} \mathrm{C}=-24.1 \%$

Twigs from base of Layer 1 WA, Sq R19, Excavation 3A assoc with carly LSA. Comment: pretreated with acid and alkali. Date suggests possible mixing with lower Layer 2 BSU.

Pta-872. Border Cave 11

$$
\delta^{13} C=\begin{array}{r}
>42,300 \\
-25.3 \%
\end{array}
$$

Charcoal from second brown sand upper layer, 2 BSU, Sq T23, Excavation $3 \mathrm{~A}$ assoc with late MSA assemblage. Comment: pretreated with acid and alkali.

\section{Pta-877. Border Cave 12}

$$
\begin{aligned}
& \begin{array}{r}
45,400+3000 \\
-2200
\end{array} \\
& \delta^{13} C=-25.0 \%
\end{aligned}
$$

Charcoal from Layer $2 \mathrm{BSU}$, Sq Q22, Excavation 3A assoc with late MSA. Comment: pretreated with acid and alkali.

Pta-1244. Border Cave 13

$\delta^{13} C=\begin{array}{r}>48,800 \\ -24.8 \%\end{array}$

Charcoal from Layer 2 BSU, Sq R21, Excavation 3A assoc with late MSA. Comment: pretreated with acid and alkali.

Pta-1274. Border Cave 14

$$
\begin{aligned}
& 47,200+4300 \\
& \delta^{13} C=-25.7 \%
\end{aligned}
$$

Charcoal from base of Layer $2 \mathrm{BSU}, \mathrm{Sq}$ Q20, Excavation 3A assoc with late MSA. Comment: pretreated with acid and alkali.

Pta-1275. Border Cave 15

$$
\delta^{13} C=\begin{gathered}
>49,100 \\
-24.4 \%
\end{gathered}
$$

Charcoal from base of Layer 2 BSU, Sq Q21, Excavation 3A assoc with late MSA. Comment: pretreated with acid and alkali.

\section{Pta-489. Border Cave 16}

$$
\begin{array}{r}
>\mathbf{4 8 , 7 0 0} \\
\delta^{13} C=-24.8 \% \text { o }
\end{array}
$$

Charcoal from $\mathrm{Sq} \mathrm{A7,} \mathrm{first} \mathrm{gray-brown} \mathrm{sand} \mathrm{upper} \mathrm{layer,} \mathrm{Level} \mathrm{A,}$ Excavation 3B. Layer grades laterally into third brown sand lower assoc with Epi-Pietersburg. Comment: pretreated with acid and alkali.

Pta-421. Border Cave 17, acid only

Pta-447. Border Cave 17, acid only

Pta-459. Border Cave 17, alkali insoluble

$$
\begin{array}{r}
\mathbf{3 6 , 0 0 0} \pm \mathbf{1 0 0 0} \\
\delta^{13} C=-25.5 \% 00 \\
\mathbf{>} \mathbf{4 7 , 5 0 0} \\
\delta^{13} C=-25.0 \% 00 \\
>\mathbf{4 8 , 3 0 0} \\
\delta^{13} C=-24.6 \% 0
\end{array}
$$




\section{Pta-463. Border Cave 17, alkali soluble}

Charcoal from Sq OZ8, first gray-brown sand lower layer, Level B, Excavation 3B. Layer grades laterally into third white ash, Layer 3 WA, assoc with Epi-Pietersburg. Comment: first two portions of samples Pta-421, -447 pretreated with acid only, remainder pretreated with acid and alkali and both insoluble fraction, Pta-459, and alkali soluble fraction, Pta-463, measured.

\section{Pta-488. Border Cave 18}

$$
\delta^{13} C=\begin{array}{r}
>\mathbf{4 8 , 5 0 0} \\
-25.4 \%
\end{array}
$$

Charcoal from Sq A8, first gray-brown sand lower layer, Level B, Excavation 3B. Layer grades laterally into Layer $3 \mathrm{WA}$, assoc with Epi-Pietersburg. Comment: pretreated with acid only.

\section{Pta-719. Border Cave 19}

$$
\begin{aligned}
& \begin{array}{r}
42,000 \\
-2000
\end{array} \\
& \delta^{13} \mathrm{C}=-24.6 \%
\end{aligned}
$$

Charcoal from Sqs OZ7 and OZ8, first gray-brown sand lower layer, Level B, Excavation $3 \mathrm{~B}$ at 25 to $46 \mathrm{~cm}$ depth. Layer grades laterally into Layer 3 WA assoc with Epi-Pietersburg. Comment: pretreated with dilute acid.

General Comment: dates for Layer 1WA (except Pta-1190) do not differ outside statistics. Combined estimated age of this level is 37,000 BP which is earliest date for early LSA industry. Underlying Layer 2BS, which contains post Epi-Pietersburg MSA and postdates pre-Iron Age human skeletal finds in cave, is at least 43,000 yr old.

\section{Nkupe Shelter series}

Nkupe rock shelter on Quaggiskirk farm (28 $\left.09^{\prime} 04^{\prime \prime} \mathrm{S}, 29^{\circ} 56^{\prime} 41^{\prime \prime} \mathrm{E}\right)$, $25 \mathrm{~km} \mathrm{~W}$ of Dundee, has $>1.7 \mathrm{~m}$ LSA deposit: 16 grindstones from upper 4 layers; points, linkshafts, and fish hooks dominate bone implements from Layer 5 upwards. Samples coll and subm 1982 by A D Mazel, Natal Mus, Pietermaritzburg.

\section{Pta-3443. Nkupe 4}

$$
\begin{array}{r}
\mathbf{2 4 8 0} \pm \mathbf{6 0} \\
\delta^{13} C=-25.2 \% 0
\end{array}
$$

Charcoal from Sq S13, top of Layer 3, Level WA1 at $15 \mathrm{~cm} \mathrm{depth;} 70 \%$ of formal tools are adzes and $10 \%$ scrapers.

\section{Pta-3269. Nkupe 1}

$3190 \pm 60$

$\delta^{13} C=-25.9 \%$

Charcoal from Sq R10, base of Layer 3, Level WA1 at 30cm depth. Comment: pretreated with acid and alkali.

\section{Pta-3275. Nkupe 2}

$3950 \pm 70$

Charcoal from Sq R11, Layer 5, Level WA2 on large rock at $65 \mathrm{~cm}$ 
depth; $40 \%$ of formal tools are adzes and 30\% scrapers. Comment: pretreated with acid and alkali.

Pta-3276. Nkupe 3

$4590 \pm 70$

Charcoal from Sq R10, Layer 7, Level WA3 at $100 \mathrm{~cm}$ depth. Comment: pretreated with acid and alkali.

Pta-3460. Nkupe 5

$5760 \pm 70$

$\delta^{13} C=-24.6 \%$

Charcoal from Sq R10, Layer 9, Level GA2 at $135 \mathrm{~cm}$ depth. Backed pieces predominate and adzes are absent. Comment: pretreated with acid and alkali.

Pta-3455. Nkupe 6 a + b

$6650 \pm 80$

Charcoal from Sq R10, Layer 10, Level RBS 2 \& 3 at $160 \mathrm{~cm}$ depth. Scrapers and backed pieces predominate, with segments common; no adzes. Comment: pretreated with acid and alkali.

\section{Mgede Shelter series}

Large Mgede rock shelter $\left(28^{\circ} 10^{\prime} 12^{\prime \prime} \mathrm{S}, 29^{\circ} 41^{\prime} 14^{\prime \prime} \mathrm{E}\right)$ ca $40 \mathrm{~km}$ W of Dundee, with $>1.1 \mathrm{~m}$ deposit. LSA assemblage consists mostly of scrapers with few backed pieces and adzes. Coll and subm 1982 and 1983 by A D Mazel.

Pta-3669. Mgede 5cm

$120 \pm 45$

$\delta^{13} C=-25.6 \%$

Charcoal from Sq J2, Layer 1, Level GBS 1 at 0 to $5 \mathrm{~cm}$ depth. Comment: cal date is post $\mathrm{AD} 1810$ but 1700 also possible.

Pta-3665. Mgede $17 \mathrm{~cm}$

$820 \pm 50$

Charcoal from Sq J2, Layer 1, Level GBS 2 at 16 to $17.5 \mathrm{~cm}$ depth.

Pta-3505. Mgede 23cm

$4390 \pm 70$

$\delta^{13} C=-24.6 \%$

Charcoal from Sq H3, Layer 1, Level ASH 1 at 13 to 23cm depth. Comment: pretreated with acid and alkali.

Pta-3508. Mgede $45 \mathrm{~cm}$ $6550 \pm 70$

$\delta^{13} C=-24.5 \%$ o

Charcoal from Sq H3, Layer 4, Level MBS 2 at 35 to $45 \mathrm{~cm}$ depth. Comment: pretreated with acid and alkali.

General Comment: of Nkupe series, above. 


\section{Sikhanyisweni Shelter series}

Sikhanyisweni rock shelter $\left(28^{\circ} 28^{\prime} 05^{\prime \prime} \mathrm{S}, 30^{\circ} 23^{\prime} 46^{\prime \prime} \mathrm{E}\right)$ with rock paintings on Valhalla farm, ca $3 \mathrm{~km}$ W of Helpmekaar, Helpmekaar dist. Overall LSA assemblage consists of $50 \%$ adzes, $30 \%$ scrapers, and $10 \%$ backed pieces. Samples coll 1982; subm 1984 by A D Mazel.

\section{Pta-3764. Sikhanyisweni 1}

$3850 \pm 60$

Charcoal from Sq J7, Layer CBS1 at 4 to $14 \mathrm{~cm}$ depth.

\section{Pta-3782. Sikhanyisweni 2}

$9700 \pm 100$

Charcoal from Sq K8, Layer CBS3 at 24 to $34 \mathrm{~cm}$ depth. Comment: pretreated with acid and alkali.

\section{Pta-3780. Sikhanyisweni 3}

$10,000 \pm 100$

Charcoal from Sq L 8, Layer CBS5 at 45 to $55 \mathrm{~cm}$ depth. Comment: pretreated with acid and alkali.

\section{Diamond 1 Shelter series}

Diamond I rock shelter ( $\left.28^{\circ} 39^{\prime} 32^{\prime \prime} \mathrm{S}, 28^{\circ} 56^{\prime} 52^{\prime \prime} \mathrm{E}\right)$ in Royal Natal Natl Park, ca $40 \mathrm{~km} \mathrm{~W}$ of Bergville, contains $1 \mathrm{~m}$ deposit with LSA assemblages. Scrapers are most abundant tool followed by backed pieces (most abundant in Layer 2) and adzes increasing from $2 \%$ in Layer 2 to $18 \%$ on surface. Samples coll and subm 1981 by A D Mazel.

\section{Pta-2974. Diamond 1.1}

$3020 \pm 60$

Charcoal from Sq Po at 3 to $10 \mathrm{~cm}$ depth in Level CBS, I ayer 1 , antedating arrival of pottery in Natal Drakensberg.

\section{Pta-3246. Diamond 1.3}

$4900 \pm 60$

Charcoal from Sq P4 at 18 to $22 \mathrm{~cm}$ depth in Level BS, Layer 3.

\section{Pta-2977. Diamond 1.2}

$2810 \pm 60$

Charcoal from Sq P2 at $25 \mathrm{~cm}$ depth in Level RBS, Layer 3, below Level BS.

General Comment: samples pretreated with acid and alkali. Cf Nkupe, above. Mazel (1984b, p 46-49) re-assigned samples to other levels, thereby forming a time sequence.

\section{Mbabane Shelter series}

Mbabane rock shelter $\left(28^{\circ} 45^{\prime} 21^{\prime \prime} \mathrm{S}, 30^{\circ} 22^{\prime} 27^{\prime \prime} \mathrm{E}\right)$ with rock paintings, ca $8 \mathrm{~km}$ W of Tugela Ferry, Msinga dist, KwaZulu. Overall ISA assemblage 
consists of $50 \%$ scrapers, 8 to $30 \%$ backed pieces, and $<30 \%$ adzes. Coll and subm 1983 by A I) Mazel.

Pta-3680. Mbabane 1

$1310+50$

Charcoal from Sq D4, pale brown sand layer, at 3 to $9 \mathrm{~cm}$ depth.

Pta-3684. Mbabane 2

$\mathbf{5 0 0} \pm \mathbf{5 0}$

Charcoal from Sq E3, gray brown sand layer, at 10 to $15 \mathrm{~cm}$ depth.

Pta-3848. Mbabane 4

$470 \pm 40$

Charcoal from Sq D2 at 10 to $15 \mathrm{~cm}$ depth in gray brown sand layer.

\section{Pta-3678. Mbabane 3}

$1520 \pm 50$

Charcoal from Sq D2, stony brown sand layer, at 17 to $19 \mathrm{~cm}$ depth, assoc with LSA and potsherds.

General Comment: charcoal in gray brown sand layer seems to be intrusive as it is much younger than overlying layer. Pta-3678 suggests contact between LSA and IA by 5 th century AD in Tugela Basin.

\section{Pta-1381. Driel Shelter}

$1780 \pm 40$

$$
\delta^{13} \mathrm{C}=-25.1 \%
$$

Charcoal from Sq E3, Layer 3, at 15 to $27 \mathrm{~cm}$ depth at Driel rock shelter $\left(28^{\circ} 46^{\prime} \mathrm{S}, 29^{\circ} 17^{\prime} \mathrm{E}\right)$, on W bank of Tugela R, ca $8 \mathrm{~km} \mathrm{SW}$ of Bergville. This ca $55 \mathrm{~cm}$ deposit contains Iron Age artifacts in top layer and LSA assemblage below. Rock paintings are visible on walls. In Layer 3 scrapers dominate but adzes and fish hooks are also present. Potsherds occur but are slightly thinner than those from upper layers (Maggs \& Ward, 1980). Coll and subm 1974 by Tim Maggs, Natal Mus, Pietermaritzburg.

\section{eSinhlonhlweni Shelter series}

eSinhlonhlweni rock shelter ( $\left.28^{\circ} 50^{\prime} 37^{\prime \prime} \mathrm{S}, 30^{\circ} 09^{\prime} 57^{\prime \prime} \mathrm{E}\right)$, Baviaanskrans farm, ca $6 \mathrm{~km}$ E of Weenen, has ca $40 \mathrm{~cm}$ Iron Age and LSA deposit. LSA assemblage consists of $50 \%$ adzes, $30 \%$ scrapers, and $10 \%$ backed pieces. Samples coll 1983; sub 1984 by A D Mazel.

Pta-3584. eSinhlonhlweni 1 $170 \pm 50$

Charcoal from Sq D3, Level BSA at 10 to $15 \mathrm{~cm}$ depth. Comment: cal date is post-AD 1660 .

Pta-3851. eSinhlonhlweni 2

$$
\delta^{13} C=\begin{aligned}
& \mathbf{3 3 0} \pm \mathbf{4 5} \\
& -25.4 \%
\end{aligned}
$$

Charcoal from Sq C3, Level BSA at $15 \mathrm{~cm}$ depth. Comment: cal AD $1500-1650$. 


\section{Clarke's Shelter series}

Clarke's rock shelter $\left(29^{\circ} 01^{\prime} 15^{\prime \prime} \mathrm{S}, 29^{\circ} 18^{\prime} 58^{\prime \prime} \mathrm{E}\right)$ in Cathedral Peak State Forest, Drakensberg, ca $40 \mathrm{~km} \mathrm{~S}$ of Bergville, has impressive rock paintings and ca $1 \mathrm{~m}$ LSA deposit. Assemblages are dominated by scrapers; adzes increase from Layer 2 to surface. Backed pieces are most numerous in Layer 2, decreasing from 33 to $4 \%$ in Layer 1. Samples coll and subm 1981 by A D Mazel.

\section{Pta-2971. Clarke's Shelter 1}

$2160 \pm 50$

Charcoal from Sq K4, at 3 to $18 \mathrm{~cm}$ depth, Layer 2, Level PBS I.

\section{Pta-2973. Clarke's Shelter 2}

$$
1580 \pm 50
$$

Charcoal from Sq K3, at 18 to $26 \mathrm{~cm}$ depth, Layer 3, Level PBS II.

\section{Pta-3247. Clarke's Shelter 3}

$$
2380 \pm 50
$$

Charcoal from Sq J3/4, at 18 to $24 \mathrm{~cm}$ depth, Layer 3, Level PBS II. General Comment: Mazel (1984b, p 29-31) re-assigned samples to other levels, thereby forming time sequence.

\section{Gehle Shelter series}

Large Gehle rock shelter ( $\left.29^{\circ} 07^{\prime} 47^{\prime \prime} \mathrm{S}, 29^{\circ} 54^{\prime} 22^{\prime \prime} \mathrm{E}\right)$ on tributary of Bushman R, $10 \mathrm{~km} \mathrm{~S}$ of Estcourt, contains $40 \mathrm{~cm}$ LSA deposit and rock paintings. Scrapers and backed pieces dominate with relatively few adzes present. Backed pieces are more abundant in lower levels (Mazel, 1984a). Samples coll and subm 1981 by A D Mazel.

\section{Pta-3243. Gehle 2}

$\mathbf{7 5 0} \pm \mathbf{5 0}$

Charcoal from 3 to $13 \mathrm{~cm}$ depth in Sq I6, Layer 1, Level MOS 1 . Decrease of segments to only $13 \%$ of backed pieces; worked bone and pottery present.

\section{Pta-3242. Gehle 1}

$1280 \pm 50$ $\delta^{13} C=-24.8 \%$

Charcoal from 3 to $10 \mathrm{~cm}$ depth in Sq I5, Layer 1, Level MOS 1, assoc with pottery and LSA assemblage.

Pta-3585. Gehle 4 $5690 \pm 70$

Charcoal from Sq J7, Layer 2, Level MOS 2 at 23 to $33 \mathrm{~cm}$ depth.

\section{Pta-3245. Gehle 3}

$$
\begin{array}{r}
\mathbf{4 3 3 0} \pm \mathbf{6 0} \\
\delta^{13} C=-25.7 \% \text { o }
\end{array}
$$

Charcoal from Sq I7, Layer 3, Level MOS 3 at 23 to $33 \mathrm{~cm}$ depth. 


\section{Good Hope Shelter}

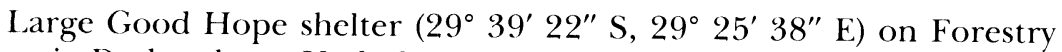
reserve in Drakensberg, Underberg dist, $52 \mathrm{~m}$ above small stream. Cave has 15 groups of painted figures on walls and deposit with LSA artifacts (Cable, Scott \& Carter, 1980). Samples coll and subm 1971 by P L Carter, Univ Mus Archaeol \& Ethnol, Cambridge, UK.

\section{Pta-838. Good Hope 1}

$$
2160 \pm 40
$$

Charcoal from $\mathrm{Sq} C 4$, Spit 3 , Layer 1 at 20 to $30 \mathrm{~cm} d e p t h$ assoc with LSA.

\section{Pta-1480. Good Hope 3}

$$
\begin{array}{r}
\mathbf{7 6 7 0} \pm \mathbf{6 0} \\
\delta^{13} C=-25.6^{0} \%
\end{array}
$$

Charcoal from Sq C4, Spit 5, Layer 3 assoc with LSA tools with many notched scrapers.

General Comment: if Belleview series, below.

\section{Shongweni South Cave series}

Large Shongweni $\mathrm{S}$ cave is $27 \mathrm{~m}$ above and overlooking Umlazi $\mathrm{R}$ at Shongweni Waterworks ( $\left.29^{\circ} 51^{\prime} 46^{\prime \prime} \mathrm{S}, 30^{\circ} 43^{\prime} 15^{\prime \prime} \mathrm{E}\right)$, ca $30 \mathrm{~km} \mathrm{~W}$ of Durban. Upper deposit contains Iron Age remains with specimens of cultivated Pennistum and Eleusine cereals; lower deposit is assoc with Stone Age (Davies, 1975). Samples coll and subm between 1971 and 1985 by Oliver Davies, Natal Mus, Pietermaritzburg.

\section{Pta-1059. Shongweni S.J3.A}

$$
\mathbf{1 1 2 0} \pm \mathbf{5 0}
$$

Organic material from surface of upper dung floor in Sq J3, Spit A, Level $1 \mathrm{~b}$, at $5 \mathrm{~cm}$ depth assoc with LSA.

\section{Pta-1837. Shongweni S.J2.A}

$$
\begin{array}{r}
1060 \pm \mathbf{4 5} \\
\delta^{13} C=-19.4 \% 0
\end{array}
$$

Organic material from base of upper dung floor in Sq J2, Spit A, Level $1 \mathrm{~b}$ at 7 to $10 \mathrm{~cm}$ depth assoc with LSA microliths and Eleusine. Comment: pretreated with acid and alkali.

Pta-1766. Shongweni S.J3.C $1200+50$

$$
\delta^{13} C=-17.2 \%
$$

Organic material from broken-up dung floor in Sq J3, Spit C at 22 to $23 \mathrm{~cm}$ depth assoc with LSA tools and pottery. Comment: pretreated with acid and alkali.

\section{Pta-821. Shongweni S.J2.B}

$$
\begin{array}{r}
\mathbf{1 7 7 0} \pm \mathbf{6 0} \\
\delta^{13} C=-16.1 \% \text { o }
\end{array}
$$

Charcoal from hearth just beneath upper dung floor in Sq J2, Spit B, Level 3 at 13 to $15 \mathrm{~cm}$ depth assoc with Eleusine and Pennisetum, pottery and tanged and barbed Late Wilton artifacts. Comment: pretreated with acid and alkali. 


\section{Pta-1060. Shongweni S.H4.C}

Heads of Sorghum, Sq H4, Spit C at $24 \mathrm{~cm}$ depth, just below twig floor. Comment: date indicates that Sorghum was placed in pit, later than Level 1, Pta-1059, -1837, above.

\section{Pta-1951. Shongweni S.J2.C}

$1100 \pm 70$

$\delta^{13} \mathrm{C}=-10.9 \%$

Pennisetum head from SqJ2, Spit C, Level 4 and 5 at 20 to $23 \mathrm{~cm}$ depth. Comment: $56 \mathrm{mg}$ carbon analyzed in mini-counter (Vogel \& Behrens, 1976). Date indicates that Pennisetum was placed in pit, assoc with Level Pta$1059,-1837$, above.

\section{Pta-4040. Shongweni S.Ji. $\lambda$}

$$
\begin{array}{r}
1960 \pm \mathbf{6 0} \\
\delta^{13} \mathrm{C}=-25.1 \% \text { o }
\end{array}
$$

Marula nuts from Sq J1, Spit $\lambda$, below Level 3, at $25 \mathrm{~cm}$ depth in later excavation, assoc with stone and bone aritifacts and underlying Iron Age levels.

\section{Pta-823. Shongweni S.J2.D(1)}

$$
3870 \pm 60
$$

Charcoal from hearth in Sq J2, Spit D, Level 6 at 32 to $39 \mathrm{~cm}$ depth, assoc with Late Wilton artifacts, barbed and tanged arrowheads. Comment: pretreated with acid and alkali.

\section{Pta-1061. Shongweni S.J2.D(2)}

$$
\begin{array}{r}
\mathbf{4 0 0 0} \pm \mathbf{6 0} \\
\delta^{13} \mathrm{C}=-22.6 \%
\end{array}
$$

Marula pods from Sq J2, Spit D, Level 6 at 30 to $40 \mathrm{~cm}$ depth, assoc with LSA microliths. Comment: pretreated with acid and alkali.

\section{Pta-1947. Shongweni S.J2.D(3)}

$$
\begin{array}{r}
\mathbf{9 0 0} \pm \mathbf{1 4 0} \\
\delta^{13} \mathrm{C}=-11.1 \%
\end{array}
$$

Pennisetum head from SqJ2, Spit D, Level 6 at 30 to $40 \mathrm{~cm}$ depth. Comment: 56mg carbon analyzed in mini-counter (Vogel \& Behrens, 1976). Date indicates that Pennisetum is intrusive at this level and assoc with Level 1, Pta-1059, -1837, above.

\section{Pta-682. Shongweni S.J3.E}

$11,900 \pm 130$

Charcoal from hearth in Sq J3, Spit E, Level I at 44 to $50 \mathrm{~cm}$, top of lower occupation, assoc with LSA artifacts.

\section{Pta-822. Shongweni S.J4.I}

Charcoal from Sq J4, Spit I, Level IV at 82 to $86 \mathrm{~cm}$ depth in lower occupation, assoc with LSA artifacts. Comment: pretreated with acid and alkali. 
Pta-966. Shongweni S.J2/3.L

Charcoal from Sq J2/3, Spit L, Level VII at 115 to $122 \mathrm{~cm}$ depth, lowest ash layer in lower occupation, assoc with some stone and bone flakes. Comment: pretreated with acid and alkali.

General Comment: results show sporadic Stone Age occupation from 23,000 to 1960 BP overlain by occupation during Early Iron Age (EIA) at ca 1100 $\mathrm{BP}$ and again at $700 \mathrm{BP}$. Earliest documented domesticated grain in Natal (Pta-1951).

\section{Shongweni North Cave series}

Shongweni N cave at Shongweni Waterworks $\left(29^{\circ} 51^{\prime} 46^{\prime \prime} \mathrm{S}, 30^{\circ} 43^{\prime}\right.$ $16^{\prime \prime} \mathrm{E}$ ); some $10 \mathrm{~m} \mathrm{~N}$ of Shongweni $\mathrm{S}$ cave (above) was excavated in 1979 and 1981 by $O$ Davies and T Maggs. Samples subm between 1979 and 1985 by $\mathrm{O}$ Davies.

\section{Pta-2601. Shongweni N.MD2}

$$
\delta^{13} C=\begin{array}{r}
\mathbf{6 7 0} \pm \mathbf{4 0} \\
-25.1 \% 0
\end{array}
$$

Charcoal from Sq X7, Layer XVII, 15 to $20 \mathrm{~cm}$ depth, assoc with pottery, Middle Iron Age (MIA).

\section{Pta-2602. Shongweni N.II 4}

$$
\mathbf{9 5 0} \pm \mathbf{5 0}
$$

Wood from trial trench at 40 to $50 \mathrm{~cm}$ depth assoc with pottery, MIA.

Pta-4159. Shongweni N.9

$1490 \pm 50$

Charcoal from Sq Y7, Layer XVIII at 22 to $23 \mathrm{~cm}$ depth assoc with top of EIA deposit.

Pta-4135. Shongweni N.8

$\mathbf{3 8 4 0} \pm \mathbf{5 0}$

Leaves from ous human occupation of cave.

\section{Pta-4134. Shongweni N.7}

$2030 \pm 45$

Charcoal from Sq X7, Layer XXIVd at 55 to $60 \mathrm{~cm}$ depth, near Stone Age/Iron Age interface.

\section{Pta-3864. Shongweni N.XXVb}

$13,800 \pm 240$

Charcoal from Sq X7, Layer XXVb beneath large fallen slab at 70 to $75 \mathrm{~cm}$ depth. Lowest spit with Ricinus seeds and chewed wads, probably Catha edulis. 


\section{Pta-4115. Shongweni N.6}

$13,600 \pm 140$

Charcoal from Sq Y7, Layer XXVd at ca $102 \mathrm{~cm}$ depth assoc with quartz and lydianite artifacts.

\section{Pta-4133. Shongweni N.5}

$\mathbf{2 5 , 2 0 0 \pm 5 7 0}$

Charcoal from Sq X7, Laber XXVIb overlying bedrock at $93 \mathrm{~cm}$ depth assoc with some bone and stone artifacts.

\section{Pta-3858. Shongweni N.XXVI.d}

$\mathbf{2 9 , 4 0 0} \pm \mathbf{5 8 0}$

Charcoal from Sq X7, Layer XXVId at $120 \mathrm{~cm}$ depth, extreme base of cave floor.

General Comment: $c f$ dates from Shongweni South cave, above.

\section{Sibudu Shelter series}

Sibudu rock shelter $\left(29^{\circ} 30^{\prime} 15^{\prime \prime} \mathrm{S}, 31^{\circ} 05^{\prime} 10^{\prime \prime} \mathrm{E}\right)$ overlooks Tongati R, ca $6 \mathrm{~km} \mathrm{NW}$ of Tongaat. Top deposit assoc with Later Iron Age (LIA) assemblage overlying MSA industry; no rock paintings are present. Samples coll 1983; subm 1984 by A D Mazel.

\section{Pta-3765. Sibudu 1}

$26,000 \pm 420$

Charcoal from Sq D6, mottled layer deposit 2, at 20 to $30 \mathrm{~cm}$ depth assoc with MSA artifacts. Comment: pretreated with acid and alkali.

\section{Pta-3767. Sibudu 2}

$24,200 \pm 290$

Charcoal from Sq D6, general ash layer area 2, at 79 to $88 \mathrm{~cm}$ depth assoc with MSA artifacts. Comment: pretreated with acid and alkali.

\section{Borcher's Shelter series}

Borcher's rock shelter $\left(30^{\circ} 42^{\prime} \mathrm{S}, 30^{\circ} 16^{\prime} \mathrm{E}\right)$ overlooking Oribi Gorge, Paddock dist. Deposit contains LSA artifacts. Samples coll and subm 1980 by Charles Cable, Dept Archaeol, Cambridge Univ, UK.

\section{Pta-3107. Borcher 17}

$$
\delta^{13} C=\begin{aligned}
& \mathbf{1 0 0} \pm \mathbf{5 0} \\
& -24.2 \% 0
\end{aligned}
$$

Charcoal from Sq D3 of $6 \mathrm{~cm}$ depth in upper gray brown earth layer. Comment: pretreated with acid and alkali. Cal date is post-AD 1820 but AD 1700 also possible.

\section{Pta-3108. Borcher 20}

$\mathbf{2 0 7 0} \pm \mathbf{5 0}$

Charcoal from Sq D3 at 20 to $50 \mathrm{~cm}$ depth, at base of dark brown earth layer. Comment: pretreated with acid and alkali. 
Pta-3110. Borcher HB

$3360 \pm 110$

$\delta^{13} \mathrm{C}=-16.9 \%$

Collagen from human skeleton from Sq B4 at 60 to $90 \mathrm{~cm}$ depth. Bones not in original relative position, assoc with large quantity of red ocher lumps and LSA artifacts. Comment: $2.5 \mathrm{~g}$ purified collagen extracted from $48 \mathrm{~g}$ bone and tooth fragments.

Orange Free State

\section{Rose Cottage Cave series}

Further samples from Rose Cottage cave near Ladybrand $\left(29^{\circ} 15^{\prime} \mathrm{S}\right.$, $27^{\circ} 30^{\prime}$ E), (Vogel, 1970, p 462; Vogel \& Marais, 1971, p 385-386). Samples coll from wall of excavation exposure and subm 1974 and 1977 by K W. Butzer, Dept Geog, Univ Texas, Austin.

\section{Pta-2067. Rose Cottage $60 \mathrm{~cm}$}

$8600 \pm 100$

Charcoal from $60 \mathrm{~cm}$ depth, Layer $6 \mathrm{~b}$, at base of Wilton sequence. Comment: ff Pta-359: $8650 \pm 80$ from Belleview, below.

\section{Pta-1417. Rose Cottage 9 soluble fr}

\section{Pta-1416. Rose Cottage 9 insoluble fr}

$23,400 \pm 200$ $\delta^{13} C=-23.3 \%$

$22,700 \pm 240$

$\delta^{13} \mathrm{C}=-23.4 \%$

Charcoal from base of Layer 6a, assoc with microlithic Pre-Wilton LSA industry. Comment: pretreated with acid and alkali and both alkali soluble and alkali insoluble fractions measured. Similarity of results suggest reliable date. $C f$ dates of ca 20,000 BP for same industry at Melikane and Sehonghong, above. In S Cape Prov Robberg industry yields similar dates (Deacon, 1982).

\section{Munro's site series}

Further samples from Munro site upstream from Oppermansdrift on Vaal R near Bloemhoff $\left(27^{\circ} 38^{\prime} \mathrm{S}, 25^{\circ} 35^{\prime} \mathrm{E}\right)$, assoc with LSA artifacts and pottery (Vogel \& Marais, 1971, p 385). Samples coll 1968; subm 1970 by R J Mason.

Pta-345. Munro 3

Charcoal from Sq B 0-5/40-50 at 10 to $20 \mathrm{~cm}$ depth.

Pta-344. Munro 2

$$
\delta^{13} C=\begin{array}{r}
\mathbf{2 8 0} \pm \mathbf{4 0} \\
-24.9 \%
\end{array}
$$

Charcoal from Sq C 5-10/10-25 at 30 to $46 \mathrm{~cm}$ depth.

General Comment: both samples pretreated with acid and alkali. $C f$ date for skeleton from site, Pta-087: $850 \pm 60$ (Vogel \& Marais, 1971, p 385). 
Cape Province

\section{Belleview Shelter series}

Belleview shelter $\left(29^{\circ} 59^{\prime} 50^{\prime \prime} \mathrm{S}, 29^{\circ} 2^{\prime} 25^{\prime \prime} \mathrm{E}\right)$ on Belleview farm in Drakensburg, ca $12 \mathrm{~km}$ NE of Ramatseliso, E Griqualand. Deposit contains LSA artifacts (Carter \& Vogel, 1974). Samples coll 1969; subm 1970 and 1971 by P L Carter.

\section{Pta-448. Belleview 18}

Charcoal from Sq E 19, Layer 1 assoc with pottery, small handscrapers, and blade cores. Comment: designated to Layer X (Carter \& Vogel, 1974, p $563)$

\section{Pta-449. Belleview 16}

$1030+50$

Charcoal from Sq E19, Layer 1. Comment: originally designated to Layer X.

\section{Pta-291. Belleview 20}

$1590 \pm 60$

Charcoal from Sq E19, Layer 2 assoc with tanged and barbed stone points, bone points, delicate bone fish hooks, and fragment of iron. Terminal pre-pottery level.

Pta-292. Belleview 22

$2330 \pm 60$

Charcoal from Sq E19, Spit 4, assoc with Wilton assemblage.

Pta-293. Belleview 25

$3280+60$

Charcoal from Sq F19, Spit 7 assoc with Wilton industry.

\section{Pta-359. Belleview 8}

$8650 \pm 80$

Charcoal from Sq G19, Spit 17 underlying Wilton industry.

\section{Pta-309. Belleview 6}

$2610 \pm 50$

$\delta^{13} \mathrm{C}=-24.3 \%$

Charcoal from Sq H15, Spit 28 assoc with early LSA. Comment: pretreated with acid and alkali. Date is far too young and charcoal probably intrusive.

General Comment: if Moshebi and Sehonghong series, above and Wonderwerk series, below.

\section{Equus Cave series}

Equus cave in Oxland Tufa at Norlim quarry $\left(27^{\circ} 37^{\prime} \mathrm{S}, 24^{\circ} 37^{\prime} \mathrm{E}\right)$ Taung dist, Bophutatswana. $2.5 \mathrm{~m}$ faunal deposit assoc with MSA and LSA assemblages. Samples coll and subm $1978-1980$ by P B Beaumont. 
Pta-2452. Equus 1 a $23 \mathrm{~cm}$

Charcoal from hearth in Sq 20I, St la upper, at $25 \mathrm{~cm}$ depth.

Pta-2495. Equus 1 a $45 \mathrm{~cm}$

$7480 \pm 80$

Ostrich egrchell from hearth in $\mathrm{Sq} 19 \mathrm{I}$, St la base, at $45 \mathrm{to} 53 \mathrm{~cm}$ depth. Comment: first $8 \%$ carbonate discarded and rest analyzed.

\section{Pta-2789. Equus 1 b $52 \mathrm{~cm}$ fr 1}

$$
\begin{array}{r}
\mathbf{5 0 6 0} \pm \mathbf{6 0} \\
\delta^{13} C=-6.5 \% 0 \\
\mathbf{5 4 6 0 \pm 7 0} \\
\delta^{13} C=-6.2 \% 0
\end{array}
$$

\section{Pta-2791. Equus 1 b 52cm fr 2}

Ostrich eggshell from Sq 20I, St $1 \mathrm{~b}$ upper, at 52 to $67 \mathrm{~cm}$ depth assoc with abraded and fresh small amorphous flakes. Comment: first $11 \%$ carbonate removed with acid; next $40 \%$ analyzed as fraction 1, final $49 \%$ analyzed as fraction 2. Small difference in results indicates slight recent contamination.

\section{Pta-2741. Equus 2a}

Tufa sheet capping from St $2 \mathrm{a}$ in $\mathrm{Sq} 22 \mathrm{~J} / \mathrm{K}$ at $120 \mathrm{~cm}$ depth, upper temporal limit of massive faunal sample in $\mathrm{St} 2 \mathrm{a}$ lower and $2 \mathrm{~b}$. Comment: first $8.6 \%$ carbonate removed with acid, rest analyzed. Ionium date (unpub) shows tufa is fallen roofblock which therefore does not date stratum.

\section{Pta-4051/57. Equus 2b 23K 221 cm}

Collagen from bone found in $\mathrm{Sq} 23 \mathrm{~K}$, St $2 \mathrm{~b}$ at 218 to $225 \mathrm{~cm}$ depth assoc with amorphous I.SA assemblage. Comment: collagen considerably degraded and result considered min date only.

\section{Powerhouse Cave series}

Powerhouse cave at Norlim quarry $\left(27^{\circ} 37^{\prime} \mathrm{S}, 24^{\circ} 37^{\prime} \mathrm{F}\right)$ Taung dist, Bophutatswana contains ca $60 \mathrm{~cm}$ deposit with LSA artifacts. Samples coll 1975; subm 1976 by A J Humphreys, Univ Western Cape, Bellville.

\section{Pta-1763. Powerhouse I}

Charcoal from Sq A, Level I at 10 to $15 \mathrm{~cm}$ depth. Comment: pretreated with acid and alkali.

\section{Pta-1508. Powerhouse $57 \mathrm{~cm}$}

Charcoal from Sq A at $57 \mathrm{~cm}$ depth overlying bedrock.

General Comment: $f$ dates from Dikbosch and Limerock, below. 


\section{Little Witkrans Shelter series}

Little Witkrans shelter $\left(27^{\circ} 39^{\prime} \mathrm{S}, 24^{\circ} 37^{\prime} \mathrm{E}\right) 0.5 \mathrm{~km} \mathrm{~S}$ of Witkrans cave, $5 \mathrm{~km} \mathrm{~S}$ of Norlim quarry, Taung dist, Bophutatswana, containing LSA assemblages. Samples coll 1978; subm 1978 and 1982 by P B Beaumont.

\section{Pta-2447. Little Witkrans $10 \mathrm{~cm}$}

$$
1490 \pm 40
$$

Charcoal from $\mathrm{Sq} 13 \mathrm{~B}$ at 10 to $15 \mathrm{~cm}$ depth assoc with pottery.

\section{Pta-3418. Little Witkrans 13B,5}

Charcoal from Sq $13 \mathrm{~B}$ at 20 to $25 \mathrm{~cm}$ depth assoc with pottery.

\section{Pta-2448. Little Witkrans $40 \mathrm{~cm}$}

Charcoal from Sq 13D at 40 to $45 \mathrm{~cm}$ depth.

\section{Pta-2490. Little Witkrans $60 \mathrm{~cm}$}

Ostrich eggshell from Sq 13B/D at 60 to $65 \mathrm{~cm}$ depth. Comment: $17 \%$ carbonate removed with acid and rest analyzed. Sample, ca $15 \mathrm{~cm}$ above bedrock, provides min date for base of Wilton culture in this area.

\section{Wonderwerk Cave series}

Wonderwerk cave $\left(27^{\circ} 50^{\prime} 45^{\prime \prime} \mathrm{S}, 23^{\circ} 33^{\prime} 19^{\prime \prime} \mathrm{E}\right)$ on Wonderwerk farm, $45 \mathrm{~km}$ N of Danielskuil, Kuruman dist, runs $140 \mathrm{~m}$ into base of Kuruman Hills, $18 \mathrm{~m}$ wide, $4 \mathrm{~m}$ to $10 \mathrm{~m}$ high. Excavations were conducted by B D Malan and L H Wells 1943/44, F E Peabody and B D Malan 1948, P B Beaumont 1978, J F Thackeray and Anne Thackeray 1979, and P B Beaumont 1981 and 1982. Largest and most complete sequence of industries and sediment in semi-arid interior of South Africa, containing ESA, MSA and LSA assemblages, and stratified engraved stone slabs (Avery, 1981; Thackeray et al, 1981; van Zinderen Bakker, 1982). Ostrich eggshell samples from Peabody Wonderwerk colln at Univ California. Coll 1948 by F E Peabody; subm 1977 by K W Butzer.

\section{Pta-2139. Wonderwerk $7 \mathrm{~cm}$}

$$
3060 \pm 40
$$

Ostrich eggshell from Sq P30 at 0 to $13.5 \mathrm{~cm}$ depth. Comment: first $28 \%$ carbonate discarded, rest analyzed.

\section{Pta-2140. Wonderwerk $32 \mathrm{~cm}$}

$$
\begin{array}{r}
\mathbf{5 9 3 0} \pm \mathbf{5 0} \\
\delta^{13} C=-7.7 \% 0
\end{array}
$$

Ostrich eggshell from Sq M28 at 31.5 to $45 \mathrm{~cm}$ depth. Comment: first $26 \%$ carbonate discarded, rest analyzed. 


\section{Pta-2141. Wonderwerk $85 \mathrm{~cm}$}

$12,380 \pm 100$

$\delta^{13} \mathrm{C}=-10.0 \%$

Ostrich eggshell from Sq N31 at 81 to $90 \mathrm{~cm}$ depth. Comment: first $11 \%$ carbonate discarded, rest analyzed.

\section{Excavation}

Subm 1979 by P B Beaumont.

\section{Pta-2542. Wonderwerk 3 top}

Charcoal from Sqs $019 / \mathrm{P} 20$, St 3 top at 10 to $15 \mathrm{~cm}$ depth assoc with Late Wilton assemblage.

\section{Pta-2543. Wonderwerk 3 base}

$$
\begin{array}{r}
2910 \pm 60 \\
\delta^{13} C=-24.9^{0} \% 0
\end{array}
$$

Charcoal from Sqs $019 / \mathrm{P} 20$, St 3 base at 15 to $20 \mathrm{~cm}$ depth assoc with Late Wilton assemblage. Comment: of Pta-2139, from 1948 excavation, above.

\section{Pta-2541. Wonderwerk 4a top}

Charcoal from Sqs P 20/21, St 4a top at 20 to $30 \mathrm{~cm}$ depth assoc with Late Climax Wilton artifacts.

\section{Pta-2544. Wonderwerk 4b}

$5180 \pm 70$

Charcoul from Sqs $019 / \mathrm{P} 20, \mathrm{St} 4 \mathrm{~b}$ at 40 to $60 \mathrm{~cm}$ depth assoc with Early Climax Wilton.

\section{Pta-2545. Wonderwerk 4c}

$$
\begin{array}{r}
5970 \pm 70 \\
\delta^{13} C=-23.3 \% 0
\end{array}
$$

Charcoal from Sqs $019 / 21$, St $4 \mathrm{c}$ at 60 to $80 \mathrm{~cm}$ depth assoc with Early Wilton. Comment: cf Pta-2140 from 1948 excavation, above.

\section{Pta-2546. Wonderwerk 4d}

$$
9130 \pm 90
$$

Charcoal from Sqs $019 / 22$, St 4 d at 80 to $100 \mathrm{~cm}$ depth assoc with Late Albany assemblages.

\section{Excavation}

Subm 1979 by I F Thackeray and A I Thackeray, Univ Stellenbosch, Stellenbosch.

\section{Pta-2779. Wonderwerk 2b}

$$
1210 \pm 50
$$

Charcoal from Sqs T 22/23, St $2 \mathrm{~b}$ at $10 \mathrm{~cm}$ depth, assoc with LSA artifacts including stone segments and bone points, and Ovis bones. Comment: cf Pta-2542 from 1978 excavation, above. 


\section{Pta-2785. Wonderwerk 3a/b}

$$
\begin{array}{r}
\mathbf{3 9 9 0} \pm \mathbf{6 0} \\
\delta^{13} C=-24.0 \%
\end{array}
$$

Charcoal from Sq R 25, St $3 \mathrm{a}$ and $3 \mathrm{~b}$ interface at $29 \mathrm{~cm}$ depth assoc with LSA artifacts, including segments, bone points, and rock engravings (Thackeray et al, 1981, p 64-67). Comment: pretreated with acid and alkali.

\section{Pta-2797. Wonderwerk 4a base}

$4890 \pm 70$

Charcoal from Sqs T 22/S 22 between travertines 4 and 5 ; St 4 a base at $45 \mathrm{~cm}$ depth assoc with ISA artifacts including segments, decorated ostrich eggshell, and bone points. Comment: pretreated with acid and alkali. Cf Pta$2541,-2544$ from 1978 excavation, above.

\section{Pta-2798. Wonderwerk 4c top}

$7430 \pm 60$

Charcoal from Sqs S 24/25 and T 24/25, St 4c top at $67 \mathrm{~cm}$ depth assoc with I.SA artifacts, oldest rock engravings (Thackeray et al, 1981, p 64-67). Comment: pretreated with acid and alkali.

\section{Pta-2786. Wonderwerk 4d top}

$10,200 \pm 90$

Charcoal from Sqs $025 / \mathrm{P} 25$, St $4 \mathrm{~d}$ top at $87 \mathrm{~cm}$ depth assoc with I SA artifacts and rock engraving. Comment: pretreated with acid and alkali. Cf Pta-2546 from St 4d from 1978 excavation, above. Result indicates that rock engraving in South Africa is at least 10,000 yr old.

\section{Pta-2790. Wonderwerk 4d base}

$$
\begin{array}{r}
\mathbf{1 0 , 0 0 0} \pm \mathbf{7 0} \\
\delta^{13} C=-22.7 \%
\end{array}
$$

Charcoal from Sqs $025 / \mathrm{P} \mathrm{25,} \mathrm{St} \mathrm{4d} \mathrm{base} \mathrm{at} 97 \mathrm{~cm}$ depth assoc with LSA artifacts. Comment: pretreated with acid and alkali. Cf Pta-2546 from 1978 excavation, above.

\section{Pta-2852. Wonderwerk 5a}

$9760 \pm 120$

Charcoal from $\mathrm{Sq} 024$, St $5 \mathrm{a}$ at $92 \mathrm{~cm}$ depth assoc with amorphous stone artifacts, probably early LSA. Comment: pretreated with acid and alkali. Apparently charcoal from overlying St 4d; cf Pta-2786 and -2790, above.

\section{Travertines}

Coll 1979 and subm 1980 by J F Thackeray.

\section{Pta-2723. Wonderwerk Trav 2}

$$
\mathbf{2 3 5 0} \pm \mathbf{5 0}
$$

Travertine 2 from Sq R29 between St $3 a$ and 4 a at 17 to $18 \mathrm{~cm}$ depth. Comment: first $17 \%$ sample removed with acid, remaining carbonate analyzed. Cf date for St 4a top Pta-2541: 4240 \pm 60 from 1979 excavation, above. 


\section{Pta-2727. Wonderwerk Trav 4}

$$
\begin{array}{r}
\mathbf{2 2 6 0} \pm \mathbf{5 0} \\
\delta^{13} C=+0.2 \% 0
\end{array}
$$

Travertine 4 from Sq T21, St 4 a at 42 to $44 \mathrm{~cm}$ depth. Comment: first $16 \%$ sample removed with acid, remaining carbonate analyzed. $C f$ date for between travertine 4 and 5 Pta-2797: $4890 \pm 70$ from 1979 excavation, Pta-2541: $4240 \pm 60$ in St 4a top from 1978 excavation, above.

\section{Pta-2728. Wonderwerk Trav 6}

$$
3360 \pm 60
$$

Travertine 6 from Sq 21 in St $4 \mathrm{c}$ at 68 to $74 \mathrm{~cm}$ depth. Comment: first $10 \%$ sample discarded, remaining carbonate analyzed. Cf date for $4 \mathrm{c}$ top Pta-2798: 7430 \pm 60 from 1979 excavation, above.

\section{Pta-2729. Wonderwerk Trav 8}

$$
\begin{array}{r}
2930 \pm 60 \\
\delta^{13} C=-0.9 \%
\end{array}
$$

Travertine 8 from Sq R 21 St $4 \mathrm{~d}$ at 88 to $94 \mathrm{~cm}$ depth. Comment: first $11 \%$ sample discarded, remaining carbonate analyzed. Cf dates for St $4 \mathrm{~d}$ top and 4d base Pta-2786: 10,200 \pm 90, -2790: 10,000 \pm 70 from 1979 excavation, above.

General Comment: these apparent ages are for carbonate and may be $1500 \mathrm{yr}$ too old, but initial apparent age of carbonate is not known. Apparently cementing took place long after deposit was laid down.

\section{Excavation}

Subm 1982 by P B Beaumont, from deeper in cave.

\section{Pta-3422. Wonderwerk 2, 1}

Portion of charred grass from fill of subcircular Feature 1 at $25 \mathrm{~cm}$ depth, Sq P 63, rim of which is concordant with surface of St 2 containing amorphous ISA artifacts with shell blades but no backed items or large scrapers. Comment: pretreated wtih acid and alkali. $C f$ dates from adjacent exposure SI-3561: 12, $160 \pm 115,-2032 \mathrm{~B}: 12,130 \pm 110$ (Beaumont, pers commun).

\section{Excavation}

Subm 1982 by P B Beaumont, from near mouth of cave.

\section{Pta-3426. Wonderwerk 3aa}

$$
\begin{array}{r}
\mathbf{2 3 1 0} \pm \mathbf{6 0} \\
\delta^{13} C=-24.4 \% 0
\end{array}
$$

Charcoal from Sq P 7, St 3 aa at $12 \mathrm{~cm}$ depth assoc with hair tentatively id as Ovis and Wilton assemblage. Comment: $c f$ Pta-2542 from 1978 excavation and Pta-2779 from 1979 excavation, above.

\section{Pta-3427. Wonderwerk P8.3aa}

$$
\begin{array}{r}
\mathbf{5 8 0 0} \pm \mathbf{7 0} \\
\delta^{13} C=-22.8 \%
\end{array}
$$

Charcoal from Sq P 8, St 3aa at 9.5 to $11.5 \mathrm{~cm}$ depth assoc with Wilton assemblage. Comment: sample should postdate Pta-3426, above. Presumably admixture from adjacent pit. 


\section{Pta-3425. Wonderwerk 4ac}

$$
\begin{array}{r}
\mathbf{6 8 4 0} \pm \mathbf{7 0} \\
\delta^{13} C=-24.0 \%
\end{array}
$$

Charcoal from Sq P 7, St $4 \mathrm{ac}$ at 68 to $71 \mathrm{~cm}$ depth assoc with Wilton assemblage. Comment: cf Pta-2545 from 1978 excavation Pta-2798 from 1979 excavation, above.

\section{Pta-3366. Wonderwerk P9.4ac}

$$
\mathbf{8 0 0 0} \pm \mathbf{8 0}
$$

Ostrich egoshell from Sq $\mathrm{P} 9 \mathrm{St} 4 \mathrm{ac}$ at $83 \mathrm{to} 84 \mathrm{~cm}$ depth assoc with Wilton base in front sec of cave. Comment: $10 \%$ carbonate discarded, rest analyzed. Cf Pta-2798 from 1978 excavation, above.

\section{Pta-3439. Wonderwerk 5, 1}

$$
\begin{array}{r}
9030 \pm 90 \\
\delta^{13} C=-8.0 \%
\end{array}
$$

Ostrich eggshell from Sq 7/9, St 5 at 85 to $90 \mathrm{~cm}$ depth assoc with small Robberg-type blades but no backed items or large scrapers. Comment: first $18 \%$ carbonate rejected and rest analyzed. Cf Pta-2852 from 1979 excavation, above.

\section{Pta-3441. Wonderwerk 5, 5}

$$
12,400 \pm 180
$$

Ostrich eggshell from Sq P7, St 5 at 93 to $98 \mathrm{~cm}$ depth assoc with small Robberg-type blades but no backed items or large scrapers. Comment: first 15\% carbonate rejected and rest analyzed. Cf Pta-2852 from 1979 excavation, above.

General Comment: base of Wilton industry (St 4c) dated by Pta-3366: 8000 \pm $80 \mathrm{BP}$; underlying late Albany industry (St 4d) dates between Pta-2546: $9130 \pm 90 \mathrm{BP}$, and Pta-2786; $10,200 \pm 90 \mathrm{BP}$, and atypical Robberg industry (St 5) dates to Pta-3441: 12,4.00 \pm 180 BP. Cf Pta-2067: 8600 \pm 100 BP at Rose Cottage and Pta-359: 8650 \pm 80 BP at Belleview Shelter, above for earliest Wilton assemblage further $\mathrm{E}$.

\section{Limerock Shelter series}

On Limerock farm (28 $\left.33^{\prime} \mathrm{S}, 24^{\circ} 0^{\prime} \mathrm{E}\right)$, Herbert dist, two adjacent shelters, 1 and 2, with LSA assemblages. Coll 1975; subm 1975 and 1977 by A J Humphreys.

\section{Pta-1621. Limerock 1.III}

$1620 \pm 50$

Charcoal from Level III, at $45 \mathrm{~cm}$ depth in Shelter 1 assoc with pottery and LSA assemblage.

\section{Pta-2095. Limerock 2.IV}

$1720 \pm 40$

Charcoal from Sq A, I evel IV at $47 \mathrm{~cm}$ depth in Shelter 2 LSA artifacts and pottery. 
Pta-1759. Limerock 2.V

Charcoal from Sq A, Level V at 55 to $60 \mathrm{~cm}$ depth in Shelter 2.

\section{Pta-360. Grootdrink 4}

$310 \pm 30$

$\delta^{13} C=-23.1 \%$

Carbonaceous material scraped from outside of pot, which was buried upside down in fireplace on Grootdrink farm $\left(28^{\circ} 33^{\prime} \mathrm{S}, 21^{\circ} 45^{\prime} \mathrm{E}\right)$ on $\mathrm{S}$ bank of Orange R, $50 \mathrm{~km}$ E of Upington, Gordonia dist, assoc with human skeletons, pots, and decorated ostrich eggshells. Coll by A S Brink; subm 1971 by Jalmar Rudner, South African Mus, Cape Town. Comment: cal AD 1530 or 1640 .

\section{Pta-3847. Waterval}

$760 \pm 40$

Charcoal from Sq C1/D1 at 0 to $15 \mathrm{~cm}$ depth from hearth at pastoralist camp site on Waterval farm (28 $\left.34^{\prime} \mathrm{S}, 20^{\circ} 21^{\prime} \mathrm{E}\right)$, Augrabies Falls Natl Park Gordonia dist, assoc with pottery, bone, and stone work. Sample coll 1984 by A G Morris and A B Smith; subm 1984 by A G Morris, Univ Cape Town, Rondebosch.

\section{Zoovoorbij Cave series}

Cave on Zoovoorbij farm (28 $\left.39^{\circ} \mathrm{S}, 20^{\circ} 58^{\prime} \mathrm{E}\right)$ on Orange R, near Keimoes, Gordonia dist. Ca $1 \mathrm{~m}$ deposit assoc with Stone Age assemblage. Samples coll and subm 1980 by A B Smith, Univ Cape Town.

\section{Pta-2871. Zoovoorbij II}

$2860 \pm 45$

Charcoal from Sq Al, Layer II at 5 to $10 \mathrm{~cm}$ depth assoc with LSA assemblage and pottery.

\section{Pta-2870. Zoovoorbij III}

$2800 \pm 60$

Charcoal from Sq B1, Layer III at $30 \mathrm{~cm}$ depth assoc with LSA assemblage without pottery.

\section{Pta-2888. Zoovoorbij VII}

$$
\begin{array}{r}
\mathbf{3 0 8 0} \pm \mathbf{6 0} \\
\delta^{13} C=-24.4 \% 0
\end{array}
$$

Charcoal from Sq B1, Layer VII at $44 \mathrm{~cm}$ depth assoc with LSA artifacts. Comment: pretreated with acid and alkali.

\section{Pta-2893. Zoovoorbij VIII}

$3440 \pm 60$

Charcoal from Sq B1, Layer VIII at 65 to $85 \mathrm{~cm}$ depth assoc with LSA artifacts. Comment: pretreated with acid and alkali. 
Pta-2889. Zoovoorbij IXa

$4140 \pm 70$

$\delta^{13} \mathrm{C}=-24.4 \%$

Charcoal from Sq B1, Layer IXa at 85 to $90 \mathrm{~cm}$ depth assoc with LSA artifacts. Comment: pretreated with acid and alkali.

\section{Dikbosch Shelters series}

Two adjacent rock shelters on farm Dikbosch $\left(28^{\circ} 39^{\prime} 8^{\prime \prime} \mathrm{S}, 23^{\circ} 54^{\prime} 9^{\prime \prime}\right.$ E) ca $45 \mathrm{~km}$ NNW of Douglas, Herbert dist, with LSA assemblages (Humphreys, 1974). Samples coll and subm between 1973 and 1982 by A J Humphreys.

Shelter 1, Area A

Pta-1065. Dikbosch 1.A.II

$3110 \pm 60$

Charcoal from Sq C2, Level II at 10 to $15 \mathrm{~cm}$ depth.

Pta-1288. Dikbosch 1.A.III

$13,500 \pm 120$

Charcoal from Sq B1, Level III at 30cm depth.

$\delta^{13} C=-24.1 \%$

Pta-1067. Dikbosch 1.A.IV

$12,500 \pm 100$

Charcoal from Sq B3, Level IV at $35 \mathrm{~cm}$ depth.

$\delta^{13} C=-24.1 \%$

Pta-1068. Dikbosch 1.A.V

$13,800 \pm 130$

Charcoal from Sq D4, Level V at $50 \mathrm{~cm}$ depth.

\section{Pta-1200. Dikbosch 1.A.VI}

$13,200 \pm 130$

Charcoal from $\mathrm{Sq}$ B3, Level VI at $65 \mathrm{~cm}$ depth. Comment pretreated with acid and alkali.

Shelter 1, Area B

Pta-3413. Dikbosch 1.B.II

$1720 \pm 40$

Charcoal from Sq 11, Level II at $25 \mathrm{~cm}$ depth.

$\delta^{13} \mathrm{C}=-24.8 \%$

\section{Pta-3412. Dikbosch 1.B.III}

$1570 \pm 40$

Charcoal from Sq 11, Level III at $35 \mathrm{~cm}$ depth.

Pta-3411. Dikbosch 1.B.V.

$8010 \pm 60$ $\delta^{13} \mathrm{C}=-24.5 \%$

Charcoal from Sq 22, Level $\mathrm{V}$ at $55 \mathrm{~cm}$ depth assoc with Wilton-type assemblage. 


\section{Pta-1507. Dikbosch 2}

Charcoal from Sq 8/9 at $45 \mathrm{~cm}$ depth from rock shelter Dikbosch 2 with ca $80 \mathrm{~cm}$ L.SA deposit.

\section{Pta-1357. Voëlfontein Burial}

$\mathbf{7 0} \pm \mathbf{6 0}$

$\delta^{13} C=-11.5 \%$

Collagen from human skeleton buried in sitting position at ca $90 \mathrm{~cm}$ depth on Voëlfontein farm $\left(28^{\circ} 47^{\prime} \mathrm{S}, 23^{\circ} 43^{\prime} \mathrm{E}\right)$ just $\mathrm{N}$ of Campbell, Kimberley dist, near Burchell's shelter. Coll 1959 by G J Fock; subm 1974 by A J Humphreys. Comment: $3.6 \mathrm{~g}$ purified collagen extracted from $36 \mathrm{~g}$ bone. Cal date is post-AD 1820.

\section{Pta-1196. Burchell's Shelter}

Charcoal from Sq EX2C at $10 \mathrm{~cm}$ depth from Burchell's shelter $\left(28^{\circ}\right.$ $48^{\prime} \mathrm{S}, 23^{\circ} 43^{\prime} \mathrm{E}$ ) near Campbell, Kimberley dist, assoc with LSA assemblage (Humphreys, 1975). Coll and subm 1974 by A J Humphreys. Comment: cal date is post-AD 1660 .

\section{Pta-681. Weltevreden Burial 1}

$$
\begin{array}{r}
\mathbf{3 3 8 0} \pm \mathbf{6 0} \\
\delta^{13} C=-10.9 \% 0
\end{array}
$$

Collagen from human skeleton at ca $1 \mathrm{~m}$ depth in grave with stone cairn on Weltevreden farm $\left(29^{\circ} 02^{\prime} \mathrm{S}, 24^{\circ} 10^{\prime} \mathrm{E}\right) 40 \mathrm{~km}$ W of Ritchie, Herbert dist. Coll 1967; subm 1972 by A J Humphreys. Comment: $9 \mathrm{~g}$ purified collagen extracted from $42 \mathrm{~g}$ bone.

\section{REFERENCES}

Avery, D M, 1981, Holocene micromammalian faunas from the Northern Cape Province, South Africa: South African Jour Sci, v 77, p 265-273.

Beaumont, P B, 1973, Border cave-a progress report: South African Jour Sci, v 69, p 41 46

Beaumont, P B, de Villiers, H and Vogel, J C, 1978, Modern man in Sub-Saharan Africa prior to 49000 years BP: A review and evaluation with particular reference to Border Cave: South African Jour Sci, v 74, p 409--419.

Butzer, K W, Beaumont, P B and Vogel, J C, 1978, Lithostratigraphy of Border Cave, KwaZulu, South Africa: a Middle Stone Age sequence beginning c 195,000 BP: Jour Archaeol Sci, v 5, p 317-341.

Cable, J H C, Scott, K and Carter, P L, 1980, Excavations at Good Hope shelter, Underberg district, Natal: Ann Natal Mus, v 24, p 1-34.

Carter, P L, 1969, Moshebi's shelter excavation and exploitation in eastern Lesotho: Lesotho, v $8, \mathrm{p} 1-11$ Middle and I ater Stone Age: World Archaeol v $8, \mathrm{p} 197-206$.

Carter, P L and Vogel, J C, 1974, The dating of industrial assemblages from the stratified sites in eastern Lesotho: Man ( $\mathrm{n} \mathrm{s}$ ), v 9, p 557-570.

Cooke, C K, 1963, Report on excavations at Pomongwe and Tshangula caves, Matopos Hills, southern Rhodesia: South African Archaeol Bull,v 18 p 73-151.

1979, Fxcavations at Diana's Vow rock shelter, Makoni district, Zimbabwe, Rhodesia: Occasional paper, Nat Mus Rhodesia A, Human sci, v 4, no. 4, p 115-148.

Davies, O, 1975, Excavations at Shongweni South Cave: the oldest evidence to date for cultigens in southern Africa: Ann Natal Mus, v 22, no. 2, p 627-662.

Deacon, J C G, (ms) 1982, The Later Stone Age in the southern Cape, South Africa: Phd thesis, Univ Cape Town. 
Gutin, J A and Musonda, F B, 1985, Faunal remains from Mufulwe rock shelter, Zambia, and their implications: South African Archaeol Bull, v 40, p 11-16.

Humphreys, A J B, 1974, A preliminary report on test excavations at Dikbosch Shelter 1, Herbert district, Northern Cape: South African Archaeol Bull, v 29, p 115-119.

1975, Burchell's shelter: The history and archaeology of a northern Cape Rock shelter: South African Archaeol Bull, v 30, p 3-18.

Jones, N, 1940, Bambata cave: a reorientation: Occasional paper, Nat Mus Sci Rhodesia, v 9, p $11-28$.

Lerman, J C, Mook, W G and Vogel, J C, 1970, C-1 4 in tree-rings from different localities in Olsson, I U, eds, Radiocarbon variations and absolute chronology: Nobel symposium, 12 th, New York, John Wiley \& Sons.

Louw, A W. 1969, Bushman rock shelter, Ohrigstad, eastern Transvaal: A preliminary investigation, 1965: South African Archaeol Bull, v 24, p 39-51.

Maggs, T and Ward, V, 1980, Driel shelter: rescue at a Late Stone Age site on the Tugela River: Ann Natal Mus, v 24, p 35-70.

Mason, R J, 1974, Later Stone Age plant remains from Kruger cave, Olifantsnek, Rustenburg district: South African Jour Sci, v 70, p 376.

Mazel, A D, 1984a, Gehle shelter: report on excavations in the uplands ecological zone, Tugela Basin, Natal, South Africa: Ann Natal Mus, v 26, no. 1, p 1-24.

1984b, Diamond 1 and Clarke's shelter: report on excavations in the northern Drakensberg, Natal, South Africa: Ann Natal Mus, v 26, p 25-70.

Musonda, F B, 1984, Late Pleistocene and Holocene microlithic industries from the Lunsemfwa Basin, Zambia: South African Archaeol Bull, v 39, p 24-36.

Plug, I, 1981, Some research results on the late Pleistocene and early Holocene deposits of Bushman Rock shelter, E Transvaal: South African Archaeol Bull, v 36, p 14-21.

Protsch, R and de Villiers, H, 1974, Bushman Rock shelter, Ohrigstad, eastern Transvaal: South Africa: Jour Human Evolution, v 3, p 387-396.

Thackeray, A I, Thackeray, J F, Beaumont, P B and Vogel, J C, 1981, Dated rock engravings from Wonderwerk cave, South Africa: Science, v $214, \mathrm{p}$ 64-67.

Van Zinderen Bakker, E M, 1982, Pollen analytical studies of the Wonderwerk cave, South Africa: Pollen et Spores, v 24, no. 2.

Vogel, J C, 1970, Groningen radiocarbon dates IX: Radiocarbon, v 12, no. 2, p 444-471

Vogel, J C and Behrens, H, 1976, A mini counter for radiocarbon dating of small samples: South African Jour Sci, v 72, p 311.

Vogel, J C, Fuls, A, Visser E and Becker, B, 1986, Radiocarbon fluctuations during the 3rd millennium BC, in Stuiver, M and Kra, R S, eds, Internatl ${ }^{14} \mathrm{C}$ conf, 12 th, Proc: Radiocarbon, v 28, no. 2B, p 935-938.

Vogel, J C and Marais, M, 1971, Pretoria radiocarbon dates I: Radiocarbon, v 13, no.2, p 378-394.

Vogel, J C and Waterbolk, H T, 1963, Groningen radiocarbon dates IV: Radiocarbon, v 5 , p 163-202.

1967, Groningen radiocarbon dates VII: Radiocarbon, v 9, p 107-155.

Walker, N J, 1980, Later Stone Age research in the Matopos: South African Archaeol Bull, v 35, p 19-24.

1983, The significance of an early date for pottery and sheep in Zimbabwe: South African Archaeol Bull, v 38, p 88-92. 